\title{
The Shadow of a Doubt: A Play in Three Acts by Edith Wharton
}

\section{Author(s): Laura Rattray and Mary Chinery}

Source: Edith Wharton Review, Vol. 33, No. 1 (2017), pp. 113-257

Published by: Penn State University Press

Stable URL: http://www.jstor.org/stable/10.5325/editwharrevi.33.1.0113

Accessed: 15-06-2017 15:11 UTC

JSTOR is a not-for-profit service that helps scholars, researchers, and students discover, use, and build upon a wide range of content in a trusted digital archive. We use information technology and tools to increase productivity and facilitate new forms of scholarship. For more information about JSTOR, please contact support@jstor.org.

Your use of the JSTOR archive indicates your acceptance of the Terms \& Conditions of Use, available at http://about.jstor.org/terms

Penn State University Press is collaborating with JSTOR to digitize, preserve and extend access to Edith Wharton Review 


\section{The Shadow of a Doubt: A Play in Three Acts by Edith Wharton}

Introduction by Laura Rattray and Mary Chinery

\section{Introduction}

The Shadow of a Doubt (ca. 1901) is an original three-act play by Edith Wharton, her only extant, original full-length play. It is an early treatment of the euthanasia theme she would address in her novel The Fruit of the Tree and features a similar situation: Kate Derwent, a former nurse, is happily married to John Derwent, but the relationship becomes strained when Derwent learns of Kate's role in assisting the death of his first wife, who had suffered a serious injury. The play was in production in 1901 but ultimately never performed. The discovery of the play offers new views of Wharton's early career and her early novels The House of Mirth, The Fruit of the Tree, and the unpublished "Disintegration." Recently discovered by Laura Rattray and Mary Chinery, the play is published in the Edith Wharton Review for the first time.

The text that follows reproduces the first of two extant typescripts of The Shadow of a Doubt in the Harry Ransom Center at the University of Texas at Austin. We have sought to reproduce the text as faithfully as possible, including idiosyncrasies, for example in the spacing of dashes, or missing or superfluous full stops. We have elected not to correct typing errors or omissions silently, but to reproduce them, followed by "[sic]." In both copies the stage directions are underlined in red, but there are no other markings. At points both copies have identical errors, but there are shortcuts in evidence with the second typescript, for example regularly referencing characters in abbreviated terms, at times citing "Lord U." for "Lord Uske," "Mrs. L." for "Mrs. Lingard," "Lord Oster" or "Lord O" for "Lord Osterleigh." Names are uppercased in the first copy of the play but lowercased in the second. To avoid an overwhelming cascade of endnotes of these very minor or formatting differences, we have recorded only word variants between first and second copy in the endnotes. 
We would like to thank Julia Masnik of the Watkins/Loomis Agency. The play and other unpublished references are published with permission of the Estate of Edith Wharton, the Watkins/Loomis Agency, and the Harry Ransom Center at the University of Texas at Austin. 


\title{
-:- THE SHADOW OF A DOUBT $-:^{-1}$
}

\author{
$\underline{\text { A Play }}$ \\ $\underline{\underline{\operatorname{In}}-}$
}

$\underline{\text { Three Acts }}$

- By -

EDITH WHARTON. 


\section{-:- CHARACTERS -:-}

JOHN DERWENT.

THE EARL OF OSTERLEIGH

THE HON. ROBERT MAZARET.

DR. CARRUTHERS

LORD USKE

CAPTAIN DULLASTON.

A FOOTMAN.

KATE DERWENT.

CLODAGH NEVIL

LADY USKE.

SYLVIA.

MRS. LINGARD.

GWENDOLINE JANE. 
SCENE I: $\quad$ A Drawing room in Lord Osterleigh's house in Park Lane.

As the curtain rises, SYLVIA DERWENT,

a girl of thirteen, is seen standing in one of the windows, looking out. LORD OSTERLEIGH, a tall, handsome man of about sixty, with a touch of authority beneath his light suave manner, enters the room limping slightly and leaning on a stick. $^{2}$

\section{LORD OSTERLEIGH.}

(Going up to Sylvia, and putting his hands caressingly on her shoulders.) I'm afraid this is rather a tame outlook for a traveller so lately returned from abroad.

SYLVIA.

(Turning as she feels his touch)

Why, grand-dad! I was just watching for the brougham, you know. It's coming to take Mamma out, isn't it?

\section{LORD OSTERLEIGH.}

\section{(Wincing slightly)}

I --- er --- believe so. I told Mrs. Derwent to consider it at her disposal while she is staying here.

SYLVIA.

\section{(Petting his hand)}

How awfully dear of you! Mamma has never had a carriage before, you know. She said I was to be sure and tell her if I saw any signs of it. It's turning her head. She's always making fun of herself like that, you know. Only fancy, though, grand-dad --- she told me once that she used to envy the girls who could always afford to take a 'bus. That was when she was in hospital. She always had to walk then. 


\section{LORD OSTERLEIGH.}

(Constrained)

Indeed?

SYLVIA.

There's the brougham now! Why it's a new one, isn't it, grand-dad?

\section{LORD OSTERLEIGH.}

Yes, it's a new one, you observant monkey.

SYLVIA.

You extravagant person! Why, the last time we were here -- two years ago, with poor Mother, I mean -- I remember you'd just bought a new brougham, that was used for the first time when it fetched us from the station. What's become of it, I wonder?

\section{LORD OSTERLEIGH.}

\section{(Gravely)}

Can't you guess, Sylvia, that I don't want the carriage that your Mother last used to be used by ---- by any one else?

SYLVIA.

(Awed)

Oh, grand-dad! ---- But not ---- not even by Mamma?

LORD OSTERLEIGH.

(Aside)

Even!

(Aloud, putting his arm about Sylvia, and drawing her away from the window.)

Sylvia, dear, is it quite necessary that you should call Mrs. Derwent Mamma?

SYLVIA.

\section{(Troubled)}

I don't know --- I suppose not. She told me to call her Kate. But father likes me to call her Mamma. 


\section{LORD OSTERLEIGH.}

\section{(Bitterly)}

The same name you gave your own mother!

\section{(With an effort)}

Well, you must do what your father wishes. -- You still think of your mother sometimes, Sylvia?

SYLVIA.

Oh, grand-dad --- of course I do!

\section{LORD OSTERLEIGH.}

You'll never forget her, shall you?

SYLVIA.

Forget her? Why, how could I? I was a big girl of eleven when she died.

\section{LORD OSTERLEIGH.}

\section{(Sighing.)}

Eleven --- yes, so you were. It's only two years ago.

SYLVIA.

And besides, Kate talks to me about her every day.

\section{LORD OSTERLEIGH.}

H'm --- indeed! And what does she say?

SYLVIA.

Just what you do, grand-dad; all about how good and kind she was, and how I must never, never, never forget her.

\section{LORD OSTERLEIGH.}

H'm!

SYLVIA.

\section{(Listening)}

But there's mamma, now -- I mean Kate. I wonder if she knows the brougham is here? 
(Running to the door)

Mamma! Mamma dear!

(MRS. DERWENT enters. Tall, slight, beautifully dressed, about 28 years old, with a shade too much warmth and eagerness of manner.)

KATE.

(In a low voice, to Sylvia, as she returns her kiss -)

Kate, dear.

(To Lord Osterleigh, coming forward)

I'm going to run out and pay a few visits before John comes back. He told me he should leave the Foreign Office earlier than usual this afternoon, so I shan't be gone long.

(A FOOTMAN enters.)

FOOTMAN.

\section{(To Kate.)}

The carriage is at the door, madam.

KATE.

Yes. Thanks.

\section{FOOTMAN}

A gentleman called to see you a few minutes ago, madam, but I said you were just going out.

KATE

\section{(Perceptibly startled)}

A gentleman -- to see me? Oh, it must have been a mistake!

FOOTMAN.

I think not, madam. It was Mr. Mazaret, and he said he'd call again later, and he wished most particular to see you and Mr. Derwent madam.

(FOOTMAN goes out.) 


\section{LORD OSTERLEIGH}

Mazaret? I thought he was still in South Africa.

SYLVIA.

(With an air of superiority)

I knew he wasn't. I saw him walking in the Park with Cousin Clodagh yesterday.

\section{LORD OSTERLEIGH.}

(Interested - and then sighing)

Ah? Indeed?

KATE.

\section{(Recovering herself)}

Mr. Mazaret --- of course! How stupid of me.

(To Lord Osterleigh, with a smile)

You see I'm not used to visitors; but I must learn to conceal my surprise.

\section{(To Sylvia)}

Where's my other glove, dear? Thank you.

SYLVIA.

Let me button it for you, mamma.

KATE.

(In a low tone, as she yields her hand)

Kate, dear - - remember!

SYLVIA.

(In the same tone)

Yes, mamma --, but can’t I say mamma if I whisper it?

\section{(Aloud)}

There --- that's beautifully buttoned. How lovely you do look - doesn't she, grand-dad? 
KATE.

(Smiling)

Fine feathers make fine birds. But I must be off now. Is there anything I can do for you, Lord Osterleigh?

\section{LORD OSTERLEIGH}

\section{(With studied politeness)}

Thanks, no. I shall stay at home and nurse my gout, and this great girl shall entertain me with an account of her travels.

KATE.

(Smiling)

Sylvia is a famous traveller, I can assure you. We weren't allowed to skip a single gallery and John had to brush up all his dates.

(To Sylvia)

Have you shown Lord Osterleigh your photographs?

SYLVIA.

No. I'll run and fetch them.

(Goes out.)

KATE.

\section{(Looking after her affectionately)}

She was so immensely interested in all we saw abroad. I'm so glad I persuaded John to take her with us. Don't you think her improved since last year, Lord Osterleigh? Isn't she growing pretty?

\section{LORD OSTERLEIGH}

\section{(Softening)}

She seems so to me.

KATE.

So --- so like her mother -- Don't you think so? 


\section{LORD OSTERLEIGH}

\section{(Stiffening again)}

I am not good at seeing likenesses.

(A pause)

But I think the brougham is here.

KATE.

\section{(Embarrassed)}

How thoughtless of me to keep it waiting!

(With a smile)

But you see, Lord Osterleigh, I'm not used to a carriage either!

(He looks a little ashamed of himself and she goes out with a nod and a smile.)

\section{LORD OSTERLEIGH}

Confound that woman! She always makes me behave like a cad. I sometimes think she does it on purpose.

\section{(A pause)}

But why did she jump so when she heard some one had called? Hang it, she's not as unsophisticated as all that.

(sYLVIA re-enters, carrying a large photograph album.)

\section{SYLVIA.}

Here they are, grand-dad. See how beautifully they're arranged. Kate gummed them all in for me. I couldn't have done it half as well myself.

\section{LORD OSTERLEIGH.}

(Seating himself beside her on a sofa, while she opens the album.) H'm -- the Coliseum, Mont Blanc, Pompeii, the Sistine Madonna. What a number of new things you saw, my dear!

SYLVIA.

\section{(Astutely)}

Oh, now you're laughing, grand-dad; father laughed at us awfully too. But you see neither Kate nor I had ever been abroad before and we wanted to see everything. 


\title{
LORD OSTERLEIGH
}

To be sure --

SYLVIA.

But here's something different. Here’s Vienna.

\section{LORD OSTERLEIGH.}

Ah, I was secretary of embassy there long before you were born.

SYLVIA.

Were you, really? What fun! Do you think father'll ever be secretary of embassy, grand-dad?

\section{LORD OSTERLEIGH}

He might have been ambassador once!

SYLVIA.

\author{
(Awed)
}

Oh ---when?

\section{LORD OSTERLEIGH.}

I mean ---if circumstances had been different. If your poor mother had lived. She was so fitted -- so wonderfully fitted-- to help him on in his career.

SYLVIA.

\section{(Sighing)}

Yes - that's what Kate always says. But Kate is trying so hard to help father too. She studied French and German all last winter on purpose.

\section{LORD OSTERLEIGH.}

H'm --- she certainly has an ardent champion in you, my dear.

\section{SYLVIA.}

I'm very fond of her, you mean? But how could I help it? She's so awfully, awfully good to me! She never minds my being just a little girl; and that's such a comfort, you know. 


\section{LORD OSTERLEIGH}

\section{(Smiling)}

Yes, I suppose it is. And all the time you were abroad was she never -- never the least little bit cross to you?

SYLVIA.

(Thoughtfully)

Oh, yes -- sometimes -- just a little.

\section{LORD OSTERLEIGH}

\section{(Frowning)}

When?

SYLVIA.

\section{(Guiltily)}

Oh, just once or twice. When I forgot --forgot---

\section{LORD OSTERLEIGH}

Well?

SYLVIA.

To write to you and Cousin Clodagh.

\section{LORD OSTERLEIGH}

$\mathrm{Ah} !$

SYLVIA.

\section{(Caressingly)}

But I didn't often forget --now did I, grand-dad?

\section{LORD OSTERLEIGH}

\section{(Smiling and pinching her chin)}

How can I tell, you monkey, if you were always reminded? 
SYLVIA.

(Disconcerted)

Oh, grand-dad ---oh!

\section{LORD OSTERLEIGH.}

\section{(With an effort)}

Well, you seem to have had a very happy year with your -- your new mother. -(A pause)

And your father--- was he always hap---

(Breaks off, rising and moving away. Then to himself)

Come, come, this will never do. I'd better hire a detective at once.

(THE FOOTMAN re-enters)

FOOTMAN.

Lady Uske, my lord.

(Goes out.)

(LADY USKE, a slender, charming, well-preserved, up-to-date woman nearing fifty, enters with an air of friendly familiarity)

\section{LORD OSTERLEIGH}

Ah, my dear Susan! What a pleasant surprise! I'd no idea you were in town.

\section{LADY USKE.}

(Smiling and giving him her hand)

I've come up for the day to call on the bride.

\section{LORD OSTERLEIGH}

Why undeceive me so quickly? I hoped you'd come up to see me.

\section{LADY USKE.}

Well, so I have. I waited till she was out. I've just passed her carriage in Bond Street --- upon my word, you turn her out remarkably well! 


\section{LORD OSTERLEIGH.}

(Slightly embarrassed)

Here is Sylvia waiting to be noticed.

\section{LADY USKE.}

Why, you great girl! How tal [sic] you've grown --I haven't seen you since you went abroad--

(She kisses Sylvia tenderly, while LORD OSTERLEIGH looks

down with a deep sigh)

How glad your grandfather must be to have you back!

SYLVIA.

\section{(Gravely)}

Yes, it's a great thing for him.

\section{LADY USKE.}

\section{(To Lord Osterleigh in a low tone)}

And now send her away please, or I shall be sure to say something improper. Children always affect me in that way. They stare so that they embarrass me and then I blurt out the wrong thing.

\section{LORD OSTERLEIGH.}

\section{(To Sylvia)}

And now, dear, I think you'd better carry your photographs back to the school-room.

SYLVIA.

\section{(Cheerfully)}

Very well, grand-dad.

(She picks up the album)

Good-bye, Lady Uske.

\section{LADY USKE.}

Good-bye, child. 
(Watching Sylvia as she goes out)

How pretty she grows! So like Agnes.

\section{LORD OSTERLEIGH}

Ah, you see it too?

LADY USKE.

Only more animation.

\section{LORD OSTERLEIGH}

(Slightly annoyed)

You speak as if Agnes had been cold.

LADY USKE.

(Without enthusiasm)

Oh, no---not to you, certainly.

\section{LORD OSTERLEIGH}

\section{(With intense emotion)}

She was a perfect daughter.

LADY USKE.

(Seating herself near him and laying her hand affectionately on his)

My poor friend!

(A pause)

You find this visit very trying?

\section{LORD OSTERLEIGH}

Oh, intollerable [sic]! It brings back all I suffered at Agnes' death. Miss Tredennis was so associated with ----

LADY USKE.

Yes ---- I know. 


\section{LORD OSTERLEIGH}

(With increasing agitation)

I can never reconcile myself to her having died with no one near her!

LADY USKE.

Except Miss Tredennis.

\section{LORD OSTERLEIGH}

\section{(Bitterly)}

Except the present Mrs. Derwent!

\section{LADY USKE.}

But at that time, I understand, she behaved admirably.

\section{LORD OSTERLEIGH.}

Admirably----I try to remember that. A sister could not have been more devoted, more heroic. The very last time I saw Sir Hector Blair---- last winter it was, just a few days before his death---- he told me that in all his professional experience he had never seen a more skilful [sic] and intelligent nurse than Miss Tredennis.

\section{LADY USKE.}

\section{(Retrospectively)}

Ah, poor dear Sir Hector! What a loss he was! I've never dared to be really ill since he died.

\section{LORD OSTERLEIGH}

\section{(Following his own thoughts.)}

But to see her here now -- to know that at Agnes' death she was nearer to my child than I was --- and that now she's usurped her place -- oh, it's intollerable! [sic] That woman in Agnes' place ---- that woman!

\section{LADY USKE.}

(Sympathetically)

Is she so perfectly awful? 


\title{
LORD OSTERLEIGH
}

Awful? No. Much worse than that. She's so perfectly irreproachable -- so damnably considerate and well-bred and tactful and self-effacing, that I can hardly bear to stay in the same room with her.

\section{LADY USKE.}

Oh, I understand that so well. She never gives you the least excuse for hating her?

\section{LORD OSTERLEIGH}

\section{(Vindictively)}

Never!

LADY USKE.

Or for being ashamed of her?

\section{LORD OSTERLEIGH}

(Same tone)

Never!

\author{
LADY USKE.
}

She's kind to Sylvia?

LORD OSTERLEIGH

Insufferably.

LADY USKE.

And John's in love with her?

\section{LORD OSTERLEIGH}

Disgustingly.

LADY USKE.

(Philosophically) 
Well -- what can you expect whan [sic] a man marries against the advice of all his friends? It's almost certain to turn out badly ---for them: [sic]

\section{LORD OSTERLEIGH}

(Sadly)

Ah, Susan, I've no doubt it seems a capital joke to you --- but to me ---- to see my Agnes, my darling, thrust aside, superseded, utterly forgotten ---within two years of her death! To see her husband, the man I had raised from obscurity for her sake, whose career I had watched over as if he had been my own son -- to see him, within a year, put into my daughter's place an upstart, a nobody----

\section{LADY USKE.}

Oh, was Miss Tredennis as bad as that?

\section{LORD OSTERLEIGH.}

\section{(Reluctantly)}

Well --- she was a clergyman's daughter, I believe.

\section{LADY USKE.}

\section{(Shocked)}

A clergyman's daughter? Good heavens, how imprudent! I don't wonder you fear the worst. ---- A lot of seedy relations too, I suppose?

\section{LORD OSTERLEIGH}

No. Not that I know of. We haven't been troubled by them yet.

\section{LADY USKE.}

Then that must have been an old admirer on the door-step -----

\section{LORD OSTERLEIGH.}

An old admirer?

\section{LADY USKE.}

Rival of John's. Didn't I tell you there was a young man enquiring for Mrs. Derwent when I came in? 


\section{LORD OSTERLEIGH.}

Ha! No. What did he look like?

\section{LADY USKE.}

Oh -- er -- well -- a kitchen-maid's idea of a Duke.

\section{LORD OSTERLEIGH.}

\section{$\underline{\text { (Aside) }}$}

There was something, then.

\section{(Aloud)}

Oh, I daresay John will have some queer hangers-on. It's one of the charms of such a marriage that a man never knows to whom he's giving the right to call him by his first name. And I always though [sic] John had a career before him! In fact, it was his immense promise -- the power I felt in him -- that reconciled me to Agnes's marrying him. At the time I should have liked her to make a different choice -- to see more of the world, at any rate, before giving the preference to a young fellow who had nothing to recommand [sic] him but his brains -- but I ended by believing in him as much as she did; and after her death the one thing that pulled me together and put a little heart in me was the thought of making him what shed wanted him to be.

\section{LADY USKE.}

But has John lost his ambition?

\section{LORD OSTERLEIGH}

\section{(Shrugging his shoulders)}

I don't know: I have seen nothing of him since this marriage. They've only been back a week, you know. But in a career like his the wife counts for so much. I am not fundamentally opposed to second marriages; I should not have been sorry to have him give Sylvia a second mother if ----

\section{LADY USKE.}

If you could have chosen her! 


\section{LORD OSTERLEIGH}

If I could have seen him choose a woman of his first wife's rank and traditions. Why, this girl was a hospital nurse -- a poor protegee [sic] of Agnes's, who took her in out of charity. She has had no experience of the world, no education, no advantages. Her whole life has been one long struggle against poverty .... You know me too well to fancy that I think the worse of for her for that; but it's hardly the training for a future Cabinet Minister's wife!

\section{LADY USKE.}

H'm --- I'm not so sure of that. I've always fancied I might have made my mark if I'd been brought up in that way.

\section{(Sighing)}

But my whole life has been one long struggle against wealth.

\section{LORD OSTERLEIGH.}

\section{(Aggrieved)}

Ah, well -- if you choose to treat the matter as a joke ---

\section{LADY USKE.}

\section{(Soberly)}

I don't indeed, my dear Osterleigh. I can quite enter into your feelings. It was John Derwent's duty either to marry the woman you wished or else some one perfectly impossible --- a barmaid, for choice ---- with a blackmailing husband in the background. The kind of lady who could be got rid of for a few hundred $t s$, without its getting into the papers.

\section{LORD OSTERLEIGH}

My dear Susan!

\section{LADY USKE.}

Osterleigh, don't be a hypocrite. You're a very ambitious man; and as you've always been too rich, too lazy, and too good-looking ---yes, I said good-looking --- to cultivate your ambitions on your own account, you've transferred them to your family --- to poor Agnes and her husband. You meant to make John a 
great man for Agnes's sake. When Agnes died you hoped he'd marry Clodagh Nevil, because she is your niece, and you wanted to keep his greatness in the family. Well, you were right --- it belonged to you in a measure. And now an interloper has robbed you of it -- and of him -- and I call it very hard on you.

\section{LORD OSTERLEIGH.}

You're shrewd enough, Susan, and there is some truth in what you say. But the slight to Agnes is what I feel! That the man who had the privilege of being her husband should marry again a year after her death --- and such a horrible death -

\section{(Walking up and down agitatedly)}

Two hours after they had parted at the station -- he was on his way to London, you remember -- she was carried home from the hunting-field, with a broken back! How could he forget so soon? Other memories are not so short, at any rate. Did I tell you I'd met Basil Mount the other day ---?

\section{LADY USKE.}

Lord Riverdene's brother?

\section{LORD OSTERLEIGH.}

Yes, an [sic] a great friend of John's. He used often to stop with them down at Winterby, and had left there the very day before the accident happened. Well, I met him at the club last week. I hadn't seen him since --- since her death, and, do you know, at the very first word he choked and had to bolt out of the room?

\section{LADY USKE.}

(Struck)

Sh ---

\section{LORD OSTERLEIGH.}

You see there are some people who don't forget her!

\section{LADY USKE.}

Ah, well, no doubt we should all have some surprises of that kind if we could come back. 
(Thoughtfully)

Though I think I know exactly what Uske would be doing.

(Consolingly)

Well, you're not the only disappointed match-maker in the world. If you wanted Clodagh, so did $\underline{\mathrm{I}}$.

\title{
LORD OSTERLEIGH
}

You? For whom?

LADY USKE.

My dear nephew, Bobby Mazaret.

LORD OSTERLEIGH

Oh ---

\section{LADY USKE.}

Oh, yes, I know; he's not going to be a Cabinet Minister, like John Derwent. But lots of nice girls would be glad to have him all the same; and here he is wasting his time over the only one who won't look at him!

\section{LORD OSTERLEIGH}

You're sure it's wasted?

\author{
LADY USKE.
}

I was last year; but now ---

LORD OSTERLEIGH.

Now?

\section{LADY USKE.}

Well, for my part, you know, I wasn't altogether sorry to hear of your son-inlaw's marriage.

\section{LORD OSTERLEIGH}

(Struck)

Why --- did you ever think ---? 


\section{LADY USKE.}

H'm ---I don't know. But Derwent is the kind of man that women always take seriously. If he goes for a walk in the rain they think he's done something heroic, whereas a boy like Bobby can get himself shot half to pieces in South Africa---

\section{LORD OSTERLEIGH.}

By Jove --- not really?

\section{LADY USKE.}

Oh, I was only putting the case hypothetically. But he has been out there, you know. He told me he'd tried everything else with her --- bankruptcy, incipient consumption, and flirting with a married woman -- and how he's tried a year's absence and come back to her with ----

\section{LORD OSTERLEIGH}

\section{(Lifting a warning hand)}

Don't say a V. C., or I shall think we're at the Adelphi.

\section{LADY USKE.}

\section{(Indignantly)}

Dear me! Nothing so commonplace. I was going to say that he'd come back without having been under fire---

\section{LORD OSTERLEIGH.}

Ah, well, if he's done anything as exceptional as that, I wonder that Clodagh can resist him.

\section{LADY USKE.}

But she does, though, the ungrateful girl!

\section{LORD OSTERLEIGH.}

Mazaret was here just now, by the way.

\section{LADY USKE.}

Was he? Then he must have heard that Clodagh was coming to call on the bride. 


\section{LORD OSTERLEIGH}

Dear me, is he as bad as that?

\section{LADY USKE.}

He's in the state when nothing cures a man but marriage -- and that almost always does.

\section{LORD OSTERLEIGH}

Susan, you have no heart.

\section{LADY USKE.}

Yes, my dear, I have; and though you've doubtless forgotten the fact, it was once very much at your disposal.

\section{(A pause) $^{3}$}

But at that time you didn't believe in second marriage -- even with a nice girl who was not a clergyman's daughter.

\section{LORD OSTERLEIGH}

\section{(Sighing)}

I had Agnes to bring up.

\section{LADY USKE.}

Thank you! But I'm not offended. I know men never marry the women who amuse them; and it was only because Uske has no sense of humour that I caught him.

\section{(Sitting down beside him)}

But all the same, you and I would have made a very jolly couple, and you wouldn't have been left here all alone to mope over the irreparable.

\section{LORS [SIC] OSTERLEIGH}

\section{(With a faint smile)}

Perhaps not.

\section{LADY USKE.}

Perhaps? What do you mean by perhaps? 


\section{LORD OSTERLEIGH}

I'm not so sure that I shouldn't have been a loser in the end.

\section{LADY USKE.}

What do you mean by the end?

\section{LORD OSTERLEIGH.}

Well --- I put it to you frankly, as a woman of experience, if I had married you -- er --- over fifteen years ago, is there any likelihood that at this moment we should be sitting here having a delightful chat over the fire?

\section{LADY USKE.}

(Convinced)

Not with each other --no, Osterleigh, certainly not with each other!

(FOOTMAN enters.)

FOOTMAN

Miss Nevil, Mr. Mazaret.

LADY USKE.

(To Lord Osterleigh)

There --- what did I tell you?

(CLODAGH NEVIL, a slight, pretty, quietly-dressed girl of about twentyfive, and MAZARET, a good-looking, good-humored young fellow of about thirty, with very good clothes and a gay inconsequent manner, enter the room together.)

MAZARET

We met on the door-step.

\section{LADY USKE}

How miraculous! 


\section{MAZARET}

How d'ye do Lord Osterleigh. How d'ye do, Aunt Sue?

\section{CLODAGH}

I didn't know you were in town, Lady Uske.

\section{LADY USKE.}

I only came up for the day. I came to call on Mrs. Derwent, but she's out, as you see, and I've been calling on Lord Osterleigh instead.

\section{MAZARET}

Well, we'll all call on Lord Osterleigh.

LADY USKE.

Oh, no, you won't, for I'm going to carry him off.

\section{LORD OSTERLEIGH.}

\section{(Surprised)}

Where to?

\section{LADY USKE.}

\section{(With marked significance, and a side-glance at the young couple)}

Why, don't you remember that you promised to go with me to see that Chippendale cabinet ----?

\section{LORD OSTERLEIGH.}

I ---- ah---- yes, of course. But the fact is I'm devilish lame to-day.

\section{LADY USKE}

(Sweetly, but firmly)

Here's my arm.

\section{LORD OSTERLEIGH}

Ah, well - then there's no more to be said. Goodbye, Clodagh. 


\section{CLODAGH}

(Kissing him)

Goodbye, uncle.

\section{LADY USKE}

Tell Mrs. Derwent I was dreadfully sorry not to see her.

(She and LORD OSTERLEIGH go out together)

MAZARET

(Gaily, drawing a chair near Clodagh)

Now we can call on each other.

\section{CLODAGH}

But you've called on me once already to-day.

MAZARET

Well, then, you can call on me.

\section{CLODAGH}

\section{(Smiling)}

A man of your character?

\section{MAZARET}

Besides, I frequently call on ladies twice in one day. This is the second time I've called on Mrs. Derwent to-day.

\section{CLODAGH}

\section{(Surprised)}

Why, you hardly know her?

\section{MAZARET}

That's the reason I'm in such a hurry to make up for lost time. 


\section{CLODAGH}

Well, it was very thoughtless of you to come just at the hour when I told you I should be here. You rattle on so that I shan't be able to talk to her at all.

\section{MAZARET}

And are you so very fond of talking to her?

\section{CLODAGH}

I haven't had many opportunities; but I want to --

\section{MAZARET}

What?

\section{CLODAGH}

Get to know her better.

$$
\text { MAZARET }
$$

Well, so do I.

\section{CLODAGH}

Ah, but I have a reason.

\section{MAZARET}

So have I.

\section{CLODAGH}

But I mean a serious reason.

\section{(A pause)}

I want to get to know her for my uncle's sake - and John's.

\section{MAZARET}

And I want to get to know her for yours. 


\section{CLODAGH}

For mine?

\section{MAZARET}

I mean for the sake of seeing you - if you're going to be here such a lot.

\section{CLODAGH}

\section{(Doubtfully)}

I don't know how much I shall be here.

\section{MAZARET}

(Leaning forward confidentially)

I say - how $\underline{\text { are }}^{4}$ things going?

\section{CLODAGH}

Here?

\section{MAZARET}

Yes.

\section{CLODAGH}

Beautifully - perfectly - but -

\section{MAZARET}

Ah, there's a but?

\section{CLODAGH}

I don't know - I can't make up my mind.

\section{(Impulsively,)}

Mr. Mazaret, you're so sensible when you're no [sic] silly --

\section{MAZARET}

Thank you so much! 


\section{CLODAGH}

That I wish you'd tell me --

(Hesitating)

what you really think of Mrs. Derwent --

(Hurriedly)

Oh, I know how odd you must think it that I should speak in this way to a friend -- for Kate $\underline{i s}^{5}$ my friend! I’ve always liked her immensely -- always believed she was the woman to make John happy; indeed it was I who persuaded me [sic] uncle not to oppose the marriage. But now that the thing is done --

\section{MAZARET}

And that they are happy --

\section{CLODAGH}

(Emphatically)

Oh, perfectly happy!

MAZARET

---You find you're not?

\section{CLODAGH}

(Earnestly)

I don't know what I find - I wish you'd help me. I like Kate as much as ever -- even my uncle admits that no one could behave with more tact and delicacy - and yet --

\section{MAZARET}

And yet?

\section{CLODAGH}

Well, there's a change somehow. She's not the same frank, straightforward girl I used to know down at Winterby. If she had a fault then, it was that of being too brusque, too positive, too careless of other people's opinion; and now he [sic] gives me the impression of trying to conciliate everybody. 


\title{
MAZARET
}

Well, you must admit that her position's a difficult one.

\section{CLODAGH}

Why should it be? We all like her - and my uncle has been very kind.

\section{MAZARET}

No doubt - but all the same, poor Mrs. Derwent is very much in the position of an insect under a microscope. You all agree that she's a remarkably fine specimen, but that doesn't prevent your pulling her to pieces.

\section{CLODAGH}

Oh--- !

\section{MAZARET}

I quite understand how you all feel about it. Lord Osterleigh can't help comparing her to his daughter, whom he idolized, and you -- well, Derwent was your friend long before you knew Miss Tredennis, and it's natural you should expect great things of his wife.

\section{CLODAGH}

\section{(Eagerly)}

Yes -- yes -- that's it. It $\underline{i s}^{6}$ natural, isn't it?

MAZARET

I know I should expect the man who married you to be --

\section{CLODAGH}

\section{(Half smiling)}

What?

\section{MAZARET}

Enough of a bore to make you deuced sorry you hadn't taken me instead.

\author{
(KATE enters)
}


Clodagh, dear! How nice of you to wait! And Mr. Mazaret too -- So glad to see you safely back. I didn't mean to stop out so late, but I've been paying such a lot of visits.

\section{CLODAGH}

How tiresome, isn't it?

\section{MAZARET}

Oh, I don't call visits tiresome! What should we do without them? They're such a splendid pretext for not seeing people.

\section{KATE}

Thank you, Mr. Mazaret!

\section{KAZARET [sic]}

Oh, I'm not calling on you -- I'm calling on John.

\section{KATE}

\section{(Gaily)}

Well, I don't find visiting tiresome; but then I've never had to do it before. Only fancy, Clodagh -- just as I was leaving cards on the Duchess of Beaumaris, in Grosvenor Square, who should go by but one of our ward doctors at Bart's! You should have seen him stare at me -- and at the carriage, and the Duchess's footmen! I could hardly help laughing in his face. Oh, don't be shocked, Clodagh. You know I can't pretend!

\section{CLODAGH}

\section{$\underline{\text { (Embarrassed) }}$}

No one wants you to, Kate, dear. But you talk as if -- as if --

\section{KATE}

I'd married John for the sake of the duchesses? Well, it's only the people who've always had what they wanted who are perfectly sure of their own disinterestedness. I married John for so many different reasons that I sometimes feel as if I'd committed bigamy. 
(With a sudden change of tone and a smile)

But then none of them would have counted if he hadn't been John!

(JOHN DERWENT, a tall man of about 38 , with a clever, serious, sensitive

face, has entered while she is speaking)

\section{DERWENT}

(Smiling at his wife as he advances toward the others)

Well, Clodagh. Hallo, Bobby. I heard this morning you were back on leave and meant to look you up later at the club.

KATE

(Intensely cordial)

Oh, tell your friends to look you up here, Mr. Mazaret! We want to see as much of you as we can -- don't we, John?

\section{CLODAGH}

(To Mazaret, in a rapid aside)

There! That's what I meant.

MAZARET

(In the same tone)

A little over-done.

\section{DERWENT}

(To Mazaret)

We're just back ourselves, you know.

(Glancing proudly at Kate)

Don't you think my wife's looking well?

\section{MAZARET}

Tremendously well.

\section{DERWENT}

We had such a good year abroad. We'd have made it two if I could have got my leave extended. 


\section{CLODAGH}

Oh, John, what would my uncle have said?

KATE

\section{(Eagerly)}

I'm quite as ambitious for him as Lord Osterleigh!

\section{DERWENT}

Yes -- she dragged me back from my first real holiday.

\section{CLODAGH}

\section{(Reproachfully)}

Your first --?

\section{MAZARET}

Oh, holidays are like love-affairs -- the last is always the first.

\section{KATE}

And now that he's back I mean to make him work.

\section{MAZARET}

\section{(To Derwent)}

They're all in a conspiracy to make you into a great man.

\section{DERWENT}

(Smiling)

When all I ask is to be a happy one!

\section{CLODAGH}

Don't they ever go together?

\section{DERWENT}

I've just left a poor fellow who has reason to think they don't. 
(To Mazaret)

Did you hear that Gerald Willoughby has had to resign?

\section{MAZARET}

No - - by Jove! Has he?

KATE

Sir Gerald Willoughby? Your old colleague at the foreign office. But I thought all his friends had been working so hard to get him appointed to Spain?

\section{DERWENT}

So they have - but -

\section{MAZARET}

(Clasping his hands in horror)

He hasn't gone and married Mrs. Castleton?

\section{DERWENT}

Yes, he has.

\section{MAZARET}

The unmitigated ass!

\section{KATE}

\section{(To Derwent)}

But I thought you told me there was no truth in those stories about Mrs. Castleton?

\section{DERWENT}

I never thought there was. And I know Willoughby doesn't think so. He's not the man to marry a woman he doesn't believe in.

\section{KATE}

Well, then---? 


\title{
DERWENT
}

Oh, well, with the world, you know, the question is not: "Is he [sic] story true?" but "Is there a story?"

\section{MAZARET}

I'm sure people are very accommodating. They never ask for proofs!

\section{CLODAGH}

Poor Sir Gerald!

KATE

\author{
(Quickly)
}

Why "poor", if he believes in her?

\section{MAZARET}

Oh, believing in a person all by oneself must be as dreary as dining alone.

\section{CLODAGH}

(To Mazaret, reproachfully)

No woman would speak in that way of a man she loved!

\section{MAZARET}

\section{(Smiling)}

And I shouldn't speak in that way of the woman who won't let me love her.

\section{DERWENT}

\section{(To his wife)}

Well, after all, one can hardly call Willoughby's position an enviable one. He's had to chuck his career, for one thing; though he's so much in love that I doubt if that counts with him - at present. But his resigning has started up a lot of old gossip --

\section{KATE}

Why should he care, if he knows it isn’t true? 


\section{DERWENT}

Well, it can't be pleasant for the most adoring husband to feel that there's even the shadow of a doubt about his wife.

KATE

(Musingly, half to herself)

Even the shadow of a doubt!

\section{MAZARET}

\section{(With sudden energy)}

Hang it all, if it came to that, there never would be about mine!

\section{DERWENT}

\section{(With a tinge of friendly irony)}

Ah --- you never mean to marry?

\section{MAZARET}

I never mean to marry a woman I don’t trust!

\section{DERWENT}

And you always mean to trust the woman you marry?

$$
\text { MAZARET }
$$

(Emphatically)

Always!

\section{DERWENT}

Even if circumstances--- ?

\section{MAZARET}

I should distrust circumstances and not her!

\section{DERWENT}

(Impulsively, with a glance at his wife) And so should I, by Jove! 
(The BUTLER and a FOOTMAN enter with the tea-tray. They place it on a low table before Kate and go out)

\section{CLODAGH}

(Rising and going toward Kate)

I must be off now, Kate, dear.

KATE

Already? Do wait for a cup of tea.

CLODAGH

It's a long way to Palace Green.

MAZARET

(In a low tone)

You'll let me see you home?

CLODAGH

(Same tone)

No.

MAZARET

Please!

CLODAGH

(Impatiently)

Don't spoil everything!

MAZARET

Why, what have I done?

\section{CLODAGH}

You've been delightful. 


\title{
MAZARET
}

\section{(Convinced)}

Oh, then I had better keep away.

\section{DERWENT}

(Who has been chatting with his wife)

Clodagh, let me ring for a cab for you.

\section{CLODAGH}

\section{(Smiling)}

You forget that I patronize the 'bus.

\section{DERWENT}

Then I'll walk to Piccadilly with you and put you in a 'bus.

\section{CLODAGH}

\section{(To Kate)}

Goodbye, dear. Give my love to Sylvia.

\section{(To Mazaret)}

Good bye.

\section{KATE}

Good bye. We'll see each other soon.

(To Derwent)

You're going on afterward to the club?

\section{DERWENT}

No, I'm coming back for a cup of tea. By-bye, Bobby. Give him a cigarette, Kate. (He and CLODAGH go out)

\section{MAZARET}

\author{
(Smiling)
}

How beautifully domestic! 
KATE

(Gaily)

Don't betray us to your fashionable friends. I don't mean to let him keep it up.

\section{MAZARET}

Keep it up?

\section{KATE}

Cream? Sugar? Help yourself, then -- Why, seeing so much of me: I know it's a mistake. But you see it's my first real taste of happiness ---

(She rises ${ }^{z}$ nervously and changes her seat)

I can't imagine why I talk to you like this!

\section{MAZARET}

My dear Mrs. Derwent!

\section{KATE}

(Smiling, but agitated)

I'm so ridiculously unused to being happy. It's like a ready-made gown that doesn't fit me.

\section{MAZARET}

Some ready-made gowns are very becoming.

\section{KATE}

Ah, but they so seldom wear well!

(A pause)

Mr. Mazaret - you do think John's happy?

\section{MAZARET}

Indecently so! 
KATE

(Handing him a silver box)

A cigarette?

MAZARET

Thanks. I may smoke?

KATE

Oh, yes. Lord Osterleigh doesn't mind.

(She lights a match and absently hands it to him)

You men are all alike, I suppose.

MAZARET

(Puzzled)

Are we?

KATE

In your judgments of women. What you said just now was dreadfully cruel.

MAZARET

(Reproachfully)

What I said?

KATE

You and John.

MAZARET

Why, we agreed we'd always believe in our wives! And really, for an unmarried man, that's pledging oneself to a lot!

KATE

Ah, but that was an afterthought. Your first impulse was to pity Sir Gerald Willoughby. 
Oh, well, a man needn't marry a Mrs. Castleton. I call that making a test case, you know.

\section{KATE}

Any woman may appear to be a Mrs. Castleton -- if she has enemies.

\section{MAZARET}

My dear Mrs. Derwent, a pretty woman needn't fear any enemies unless she's had - too good friends.

\section{KATE}

Ah, the women you know have been sheltered -- protected -- but there are others --

(She rises and then seats herself again behind the tea-table -)

\section{MAZARET}

(After a pause)

Mrs. Derwent -- you seem troubled -- If there is anything --

\section{KATE}

\section{(Quickly)}

Troubled? I? I was only thinking of that poor woman. When you're in a bright cosy room, by a warm fire, do you never think

(With a gesture toward the window)

of the poor wretches outside in the rain?

\section{MAZARET}

\section{(Rising and taking her hand)}

I always shall -- after this.

KATE

\section{(Nervous, smiling)}

Yes, do! 
Good-bye, Mrs. Derwent.

KATE

Good-bye.

(He goes out)

(She walks to the window and stands there looking out. Then she turns back into the room and wanders toward the tea-table. On the way she picks up a photograph of Derwent, looks at it smilingly a moment. Then she sits down by the tea-table and pours herself out a cup of tea. (The FOOTMAN enters)

\section{FOOTMAN}

Dr. Carruthers.

(CARRUTHERS, a pale good-looking, broken-down man of about thirty, dressed with an attempt at smartness, but looking ill, poor and insolent, enters with an air of easy assurance

\section{CARRUTHERS}

Mrs. Derwent ---

\section{KATE}

(At the sound of the name starts up and stands as if turned to stone; then rousing herself as she becomes aware of the footman's presence, advances toward Carruthers, saying with a forced smile)

Ah, how d'ye do, Dr. Car. --

(As the FOOTMAN goes out, she withdraws her hand, shrinks back and breaks out wildly)

How dare you -- how dare you?

(She drops into a chair and hides her face in her hands)

\section{CARRUTHERS}

(Calmly, in a low tone)

If you'll only take it quietly --- 
(Indignantly)

Quietly?

\section{CARRUTHERS}

Yes; not behave as if there were a mad dog in the room.

(With an attempt at gaiety)

It's like having a tooth out, you know: the quieter you keep the sooner it's over.

KATE

(Rising and speaking with a violent effort at self-control)

This house is Lord Osterleigh's.

\section{CARRUTHERS}

(Insolently)

Oh, I've visited it before. You know the state drawing-rooms are shown to the public on Tuesdays. Lady Agnes once gave me a card.

KATE

(Suffocating)

You've no right to be here!

\section{CARRUTHERS}

Oh, come -- as good a right as you.

\section{KATE}

(With growing terror)

Lord Osterleigh may come in at any moment.

\section{CARRUTHERS}

Well, I'm not afraid to meet him. 
My husband - - -

\section{CARRUTHERS}

I'm not afraid to meet him.

(He advances toward her with a deprecating gesture)

Come, Miss -- Mrs. Derwent, I mean. Let's discuss this question on a reasonable basis. I don't want to make myself any more obnoxious than I can help. I'm not a stage villain trying to frighten the heroine in order to give the hero a chance to rescue her. I'm simply a poor devil who's down on his luck. You know what I've been through. For the last two months --ever since the child died -- my wife's been at the point of death. I haven't enough left to buy medicine for her, and we shall be turned into the street if I can't rake up one hundred by the end of the week. I wrote you all this --

KATE

And I wrote you --

\section{CARRUTHERS}

That you hadn't the money. Yes; here's your letter.

(He draws an envelope from his pocket, shows it to her and puts it carefully $\underline{\text { back) }}$

I always keep your letters. But that excuse won't do you know. Look at this house!

(He glances about the room)

Look at that gown you've got on! And I saw you out just now in a smart carriage with two servants.

\section{KATE}

What I have told you was true; I haven't five pound [sic] in my purse. This house isn't mine -- the carriage wasn't mine --

\section{CARRUTHERS}

Your jewels are yours, though, I suppose? 
(Startled)

My jewels?

\section{CARRUTHERS}

I saw you leaving this house the other evening -- to dine out, I suppose. Your cloak was open and you had a string of stones around your neck -- sapphires, I think.

(A pause)

Weren't they?

KATE

This is too much! I refuse to listen to you another moment.

(In a faint voice)

I -- I will send you the money as soon as I can - - if you'll go at once.

\section{CARRUTHERS}

H'm. I'm afraid that's rather too indefinite.

\section{KATE}

If I can't get the money to-morrow I'll - - I'll borrow -- pawn - whatever people do - I'll send you something -- I promise you.

\section{CARRUTHERS}

\section{(Firmly)}

To-morrow's too far off when a man's starving. Yes -- that's that [sic] I am. I haven't touched a mouthful for two days. My last shilling went this morning to buy her a bottle of milk. My God, woman, can't you see I'm desperate?

(He turns away abruptly and seats himself with an air of deliberation)

KATE

(Terrified.)

What do you mean to do? 


\section{CARRUTHERS}

To wait here till you get me that necklace - -

KATE

I can't!

\section{CARRUTHERS}

Or till your husband comes in.

\section{KATE}

\section{(To herself.)}

John!

\section{(She turns to Carruthers and speaks pleadingly.)}

Dr. Carruthers - - I can't give you the necklace. My husband gave it to me when we were married - - he expects me to wear it - he would question me - -

\section{CARRUTHERS}

A woman can always find an answer.

\section{KATE}

I can't do it!

\section{CARRUTHERS}

I can wait.

KATE

You don’t dare - -

\section{CARRUTHERS}

What have I to lose?

\section{KATE}

No one would believe you - - 


\section{CARRUTHERS}

We'll see.

KATE

No - no - no.

\section{CARRUTHERS}

(Sneeringly.)

You don't dare!

KATE

(Beside herself.)

Oh, my God!

(She looks at him wildly a moment - then cries out.)

You'll go instantly?

CARRUTHERS

Instantly.

KATE

You'll leave me in peace - you won't come back?

\section{CARRUTHERS}

Not if they're as good stones as I think.

KATE

(Desperately)

Wait then - it's upstairs.

(She goes out.)

(CARRUTHERS left alone, glances about the room for a moment, then goes to the door and looks out. Returning, he darts toward the tea-table, pours out a cup of tea with a shaking hand, swallows it at a gulp, pounces on the cake and toast and devours them with a kind of ravening fierceness, like a hungry animal.) 


\section{CARRUTHERS}

Ah!

(He pours himself a second cup- As he is about to raise it to his lips the door opens and JOHN DERWENT enters.)

DERWENT

(With a start, in a voice a [sic] deep emotion)

Dr. Carruthers! -

(He advances and holds out his hand.)

\section{CARRUTHERS}

(Setting down the cup, with an embarrassed air.)

Mr. Derwent - -

(They shake hands.)

\section{DERWENT}

(Still deeply agitated.)

I had no idea you were in London.

\section{CARRUTHERS}

I - - I have been here for nearly a year now.

\section{DERWENT.}

Ah? You've given up your practice at Winterby, then?

\section{CARRUTHERS}

Yes.

\section{DERWENT.}

I hadn't heard of your leaving. I've not been down there since - since Lady Agnes's death. 


\section{(A pause.)}

In fact, I think the last time I saw you was - -

(His voice breaks.)

\section{CARRUTHERS.}

Yes.

\section{DERWENT}

I'm sorry you shouldn't have let me know you were in London. But the fact is I've been abroad myself for the last year.

\section{(Another pause.)}

You may have heard that I have married Miss Tredennis - -

\section{CARRUTHERS}

Yes, I read of it in the papers. And having known Miss Tredennis at Winterby, when she was - at the time you speak of - I ventured to call this afternoon and offer her my good wishes - - on her marriage.

(Hesitatingly.)

I hope it was not a liberty, but Miss Tredennis was very kind to me when I was sent for at the time - - of the accident.

\section{DERWENT}

Mrs. Derwent has often spoken to me of the skill and devotion you showed. She will be glad to see you, I am sure - - You're practising here, I suppose?

\section{CARRUTHERS}

I - - er - - yes [sic] That is, I had what seemed a good opening - - the opportunity of buying out a long-established practice at Hampstead - I came up from Winterby for that purpose; but unluckily I fell ill on first arriving - typhoid fever - and I'd hardly recovered when my wife was confined. The child died and she has been in a critical condition ever since. I lost the chance of buying the practice that was offered me, and things have been going from bad to worse with me. 
(Abruptly.)

I didn't mean to tell you this, Mr. Derwent, but I - you saw what I was doing when you came in - -

\section{DERWENT}

(Smiling.)

Taking a cup of tea, I think?

\section{CARRUTHERS}

(With a laugh.)

My first meal in two days!

\section{DERWENT}

(Startled.)

Good heavens! I'm sorry - - I'd no idea - -.

(He goes up to the desk and seats himself.)

My obligations to you give me the right to take this matter in hand at once. Personally, I can't offer you more than temporary assistance, but Lord Osterleigh is in a position to help you to a permanent opening - - possibly in one of the hospitals, or something of the sort.

\section{CARRUTHERS}

You're more than kind. I hadn't hoped - -

\section{DERWENT}

\section{(Kindly)}

Lord Osterleigh has of course heard of you from Mrs. Derwent. He will thank me for sending you to him. But owing to his ill-health he sees no one on business who doesn't first present a written application, so I will give you a few lines which you can ask his secretary to transmit.

(He writes a brief note, addresses it, and hands it to Carruthers who receives it with a confused murmur of thanks.) And now - - if you'll accept a small sum in the meantime - -

(He opens a cheque book, writes a cheque, tears it out, rises from the table, and hands the cheque to Carruthers.) 
KATE, holding a small morocco case in her hand, enters unperceived as CARRUTHERS takes the cheque. She stands aghast on the threshold and then moves suddenly forward.)

KATE

(Uncontrollably.)

John - - I - -

She stops, feeling Carruther's [sic] eye fixed on her, and seeing DERwENT's look of surprise. Then she says faintly, to her husband.)

I didn't know you were here - -

\section{CARRUTHERS}

(Advancing absequiously [sic] to her.)

How d'ye do, Mrs. Derwent?

KATE

(Stammering.)

How d'ye do, Dr. Carruthers - -

\section{DERWENT}

(To Kate.)

You're startled, dear? It's a shock to you to see Dr. Carruthers so unexpectedly? (To Carruthers.)

My wife inevitably associates you, as I do, with the saddest scene in our lives.

(To Kate.)

You have probably not see [sic] Dr. Carruthers since - - Winterby.

KATE

(With an intense effort.)

N- - no.

\section{DERWENT}

But you've often told me how much we all owe him for his devotion to - to Agnes - at that time - - 
(In a low voice.)

Yes.

\section{DERWENT}

And I know you will be as glad as I am that he should have come to us at a time when he himself is in need of help and sympathy.

\section{CARRUTHERS}

\section{(To Kate.)}

Mr. Derwent has been more than kind. He found out that I've been unlucky since I left Winterby, and he has generously offered to help me.

(He turns to Derwent and holds out his hand.)

I'm a bad hand at expressing my gratitude - but I'll - - I'll try to prove it - -

(He turns to leave the room.)

\section{DERWENT}

My dear man, there need be no such formalities between us. I should have been seriously annoyed if you hadn't let me know you were in trouble. And Lord Osterleigh will feel as I do.

\section{CARRUTHERS}

Thank you - - thank you.

(Pointedly to Kate.)

Good-bye, Mrs. Derwent.

(Kate inclines her head without speaking.)

\section{DERWENT}

You have the letter to him?

\section{CARRUTHERS}

(Pausing on the threshold.)

Yes, thanks, I have it. 
(With a sudden start.)

The letter? What letter?

\section{DERWENT}

I've given Carruthers a line to Lord Osterleigh. He told me last week there was a vacancy on one of his medical boards.

\section{KATE}

(Slowly.)

And you've - - recommended Dr. Carruthers - - to Lord Osterleigh?

\section{DERWENT}

It's hardly a question of recommendation. Lord Osterleigh knows as much as I do of Dr. Carruther's [sic] capabilities. You have so often spoken to us both of the help he gave you at Winterby - during those dreadful hours before Blair came - - and at the end - -

KATE

\section{(Faltering.)}

Yes - -

\section{DERWENT}

I've simply called my father-in-law's attention to the fact that Carruthers is looking out for something to do.

KATE

But - - Lord Osterleigh has so many demands - -

\section{DERWENT}

\section{(Surprised.)}

Not from me.

KATE

(Quickly.) 
Of course not! But you know how many people go to him for help. I - - I don't think we ought to add to the number - -

\section{DERWENT}

Never fear, I'll explain the circumstances to him.

(He holds out his hand to Carruthers.)

And I hope this will be the beginning of better things for you.

(They shake hands, and CARRUTHERs, with a murmur of thanks, turns to leave the room.)

KATE

\section{(Advancing toward him.)}

Dr. Carruthers!

\section{CARRUTHERS}

(Pausing with his hand on the door.)

Yes?

KATE

You must give back that letter.

\section{CARRUTHERS}

(Startled, but keeping himself in hand.)

I beg your pardon?

KATE

(In a clear determined voice.)

The letter to Lord Osterleigh - -

\section{CARRUTHERS}

But - -

\section{DERWENT}

(Rapidly to his wife, in a low tone.)

You have some reason for this? 
KATE

(In the same tone)

Yes! ${ }^{8}$

DERWENT

Then you owe it to the man to explain yourself.

KATE

(Resolutely.)

No! ${ }^{9}$

KATE

(To Carruthers.)

Will you please return that letter to my husband?

CARRUTHERS

Really - - I - - hardly understand - -

\section{DERWENT}

(To his wife.)

Kate, you are putting me in a very awkward position. Since you have gone so far you must explain yourself.

\section{KATE}

Dr. Carruthers does not require any explanation. He knows my reason.

\section{DERWENT}

(Turning sharply on Carruthers.)

Do you?

\section{CARRUTHERS}

(After a brief pause, speaking with great deliberation.)

Yes - - it is that I know too much of Mrs. Derwent.

KATE

Ah - -! 


\section{DERWENT}

(Furiously, springing toward him.)

You - - you infernal blackguard, you!

KATE

(Wildly.)

John - John!

\section{DERWENT}

(Controlling himself by a great effort.)

Mrs. Derwent's wish is sufficient. Give me back that letter.

\section{CARRUTHERS}

(Suddenly at bay and dangerous.)

No, by God, I won't! I didn't ask you for the letter - -or for anything else - it was your own idea to give it to me; but I'm not going to have it taken back without a word, as if I were a thief that you'd caught going off with your over-coat. If Mrs. Derwent won't explain, I will. She doesn't want me to present this letter to Lord Osterleigh, because she's afraid I'll talk.

\section{DERWENT}

(Still controlling himself.)

Talk? About what?

\section{CARRUTHERS}

(In an insolently confidential tone.)

Why - - about what happened down at Winterby.

\section{DERWENT}

At Winterby? When?

\section{CARRUTHERS}

At the time of Lady Agnes's death.

KATE

(Uncontrollably.)

John - - oh, John - - I - - 


\section{DERWENT}

(Sternly.)

Be silent. I must know the meaning of this.

(To Carruthers.)

Explain yourself.

\section{CARRUTHERS}

It's simple enough. Mrs. Derwent doesn't want that little matter about the chloroform to get out.

KATE

Oh! -

DERWENT

The chloroform?

\section{CARRUTHERS}

That she asked me to give Lady Agens [sic] - after Sir Hector Blair left

\section{DERWENT}

Chloroform, Mrs. Derwent asked you to give Lady Agnes - ? To quiet the pain - ?

\section{CARRUTHERS}

(Significantly.)

To stop it - altogether.

KATE

(Wildly.)

John - -

\section{CARRUTHERS}

To make an end - that's what she said.

KATE

John - I - - 


\section{DERWENT}

(To Carruthers, without heeding his wife.)

Go on.

\section{CARRUTHERS}

She came to me after Sir Hector left and asked if Lady Agnes was likely to suffer much. I said she would probably suffer horribly. "Then we must put an end to it," she said.

\section{DERWENT}

Go on.

\section{CARRUTHERS}

And so she told me to wait till the maid had gone downstairs to her tea, and then to bring the chloroform to Lady Agnes's room. I did as she told me, and half an hour later she called me again.

\section{DERWENT}

Well? -

\section{CARRUTHERS}

This time Lady Agnes was dead.

\section{DERWENT}

\section{(Starting and then falling back, as though blinded.)}

You - - ah - - you. - -

KATE

John - oh, John!

\section{DERWENT}

(Turning to her, and speaking in a low panting voice.)

You must have some answer - to this infamous lie.

(There is a pause.) 
KATE

(Raising her head, looks straight at her husband, and speaks in a clear composed tone.)

It is not a lie.

\section{DERWENT}

(Deathly pale)

Not a - ?

KATE

(Steadily.)

I did give Agnes chloroform. When Sir Hector Blair told me that her back was broken and that there was no hope, I determined not to let her suffer.

(DERWENT half-turns from her with $\mathrm{a}^{10}$ repressed shudder.)

She was very strong and her agony would have been awful. I spared her that. I am not sorry.

(She sinks into a chair.)

\section{DERWENT}

(After another long silence.)

You never - - told me of this....

KATE

I knew it would cause you needless pain; and you see I was right.

(She speaks slowly and painfully, but keeps her eyes on her husband's face.)

But if you had been there ... and seen what I saw ... and known what was coming, as I did . . Ah!

(She hides her face in her hands. Then, raising her head, she continues.) I've nursed such cases in hospital. .

(She turns and looks at Carruthers.)

And now - - will you send this man away? 


\section{DERWENT}

(In a low voice.)

Yes.

(To Carruthers.)

Go.

\section{CARRUTHERS}

(Quietly.)

One moment, please. You asked me for my story - -

DERWENT

Well?

\section{CARRUTHERS}

And Mrs. Derwent has told hers instead.

(A pause.)

They differ.

\section{DERWENT}

In what respect?

\section{CARRUTHERS}

(With cruel deliberation.)

Mrs. Derwent says that Sir Hector Blair told her Lady Agnes's injury was fatal. He did not say so to me.

\section{DERWENT}

You mean - -?

\section{CARRUTHERS}

That a broken back is no longer regarded as a fatal injury. It was a point no surgeon could pronounce on at the monent [sic]. Since the introduction of the aseptic method in surgery there have been several cases of partial recovery. 
(An intense silence.)

Lady Agnes might have lived.

\section{KATE}

Ah! - -

\section{DERWENT}

(Still controlling himself, and speaking in a dry monotonous tone.)

Even if - - such exceptions occur - as you say - the accident is still generally regarded as fatal - is it not?

\section{CARRUTHERS}

Perhaps - by people in general.

\section{DERWENT}

Then Mrs. Derwent - -

\section{CARRUTHERS}

Mrs. Derwent was a hospital nurse.

\section{DERWENT}

(Starting toward him again, and again holding himself back.) Then? - -

\section{CARRUTHERS}

\section{(With a sneer.)}

I leave the facts to you. Mrs. Derwent asked me for the chloroform [sic] I was a weak fool and gave it to her. I didn't realize what I'd done - - what she had done - - till she called back to the room. Then it was too late. I never meant to speak of this; but luck has gone against me, and if Mrs. Derwent chooses to stand in the way of my making an honest living, why, I must defend myself, that's all!

\section{KATE}

(Speaking with sudden firmness.) 
To make my husband believe this you must show a motive. Lady Agnes Derwent was my best friend.

\section{CARRUTHERS}

(Insolently.)

Down at Winterby people said it was Mr. Derwent.

KATE

Oh - - !

\section{DERWENT}

You scoundrel - -

(Pointing to the door.)

Not another word!

\section{CARRUTHERS}

Oh, come - gently, Mr. Derwent. I'm not going to be kicked out like a dog because Mrs. Derwent chooses to take away my character. I tell you the facts as they would appear to any medical man. If they're not true, why is Mrs. Derwent afraid of having them stated? Why has she been trying for a year to keep me quiet?

\section{DERWENT}

A year - -?

(He looks involuntarily at Kate.)

\section{CARRUTHERS}

(Recklessly.)

Oh, I never thought of making use of what I knew till luck went against me. Then I wrote to Mrs. Derwent for help, and when she refused I - - well, I reminded her of certain things - and after that she kept me supplied - -.

(He draws a packet of letters from his pocket, and holds them out to Derwent.) 
Here are her letters. . .London. . . Rome. . .Basle. . .Paris. . .London again - I know just where you went on your honeymoon! The sums weren't large and so she had to write often - - Why did she do it if she wasn't afraid of me? And why did she go upstairs just now to fetch her sapphire necklace because the money had run short? If you don't believe me, ask her what she's got in that box!

(DERWENT turns involuntarily to his wife and recognizes the morocco box. $\underline{\text { She holds it out to him, but he puts it aside with a gesture of refusal.) }}$

\section{KATE}

\section{(With sudden violence.)}

Yes - these are my letters; yes - - I fetched this necklace to give him, yes, I would have sold the clothes off my back to bribe him with, because I knew there was no way of disproving his infamous charges, and I had the right to spend on my happiness the money that other women lavish on jewels and gowns!

\section{(A terrible silence.)}

And now which of us two are you going to believe? Me, Kate Tredennis, Agnes's friend and your wife, or this miserable blackmailer, who boasts of having lived on a helpless woman's fears, and whose persecution did not begin till Sir Hector Blair, the only witness against him was dead? I ask you, which of us two?

\section{DERWENT}

\section{(In a suffocated voice.)}

Kate - -

\section{KATE}

\section{(Confronting him suddenly.)}

Ah - - it must be one or the other, you know! Even now I should have been safe if I had chosen to let Lord Osterleigh pay for my safety - but I didn't hesitate and neither must you. If you believe this man I leave your house on the instant - - if you believe me, there is no room for him here!

\section{DERWENT}

Kate - - 
KATE

Ah - - not another word! I tell you his presence degrades me!

(There is a short pause.)

\section{DERWENT}

(Turning suddenly on Carruthers, seizes him by the shoulders and flings him out of the door.)

You hound!

(As the door closes on Carruthers, DERWENT turns back and moves slowly toward his wife, who stands motionless at the other side of the stage.)

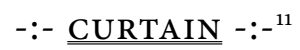




\section{-:- THE SHADOW OF A DOUBT -:-}

A PLAY IN THREE ACTS.

- By -

EDITH WARTON. [SIC]

$\underline{\underline{\text { ACT II. }}}$ 


\section{$-:-\underline{\underline{A C T ~ I I ~}}-:-$}

SCENE I. The garden of the Derwent's house on

the Thames. The house in the back-

ground, right. Terrace and sloping

lawn, with groups of basket chairs

under trees, and a tea table.

CLODAGH NEVIL and MAZARET stroll in

from the left.

MAZARET.

(Looking irritably over his shoulder)

No one in sight for the moment! Perhaps we may have time to say two words to each other at last. What a crazy idea to celebrate one's wedding day by filling up the house with people!

\section{CLODAGH.}

(Thoughtfully)

Kate seems to have grown quite mad about society. I believe she hates to be alone.

MAZARET.

Alone with Derwent?

\section{CLODAGH.}

I don't know ---

(She seats herself)

MAZARET.

After two years!

(He sits beside her and takes her hand.)

I hope we shan't have this kind of an anniversary---quite so soon.

\section{CLODAGH.}

\section{(With conviction)}

Oh, no! 
MAZARET.

There is something wrong here, isn't there?

\section{CLODAGH.}

\section{(Evasively)}

They're perfectly devoted to one another.

MAZARET.

Yes --- and always apart!

\section{CLODAGH.}

John has his work.

\section{MAZARET}

And on Sundays, when he's free, she fills the house with people!

\section{CLODAGH.}

\section{(Smiling)}

I'm sure you're very ungrateful. If she didn't you wouldn't be here.

MAZARET.

Much good it does me! What's the use of being engaged to a girl when you're never alone with her long enough to tell her how much you 1---

\section{CLODAGH.}

(Starting)

Lady Uske!

\section{MAZARET.}

\section{(Discouraged)}

I knew it!

\section{(LADY USKE and KATE enter)}

KATE.

You must be tired. It was hot on the river. Let me give you some iced tea. 


\section{LADY USKE.}

Tired? Not a bit of it. There's nothing I enjoy so much as going out with Uske. It positively refreshes me to see him boring other people.

(THEY all gathered around [the] tea-table)

\section{MAZARET.}

Who is he boring now, Aunt Susan?

\section{LADY USKE.}

Oh, poor little Mrs. Lingard, as usual. He is out in a punt reciting poetry to her. Poor dear, she does it on her husband's account.

(To Kate)

But where is your husband, my dear? I haven't seen him since luncheon.

KATE.

He's driving down to the station to fetch Lord Osterleigh. They ought to be here in a few moments.

\section{LADY USKE.}

\section{(Rising)}

Let's stroll to the gate and meet them.

(Lady Uske and Kate go out.)

\section{MAZARET.}

\section{(Making a pencil-mark on his cuff)}

Seventeen---

\section{CLODAGH.}

What are you doing?

\section{MAZARET.}

Scoring the number of times we've been interrupted. This is the seventeenth time since luncheon that I've tried to tell you how much I 1 --- 


\section{CLODAGH.}

(Starting)

Lord Uske!

MAZARET.

(Resigned)

Naturally.

(CLODAGH and MAZARET withdraw to the back of the stage while

Lord USKE and MRS LINGARD advance from the left. He is a solemn,

vapid, heavy-looking man of about sixty, with dyed hair and a

drawling monotonous voice. She is a little round eyed goose

of twenty.)

\section{LORD USKE.}

Mine is a nature that starves without sympathy.

(MRS. LINGARD sighs and looks down)

There may be others who can fight their way through life alone, but I need a heart to lean on. Perhaps it is a weakness -- it may be a weakness---

MRS. LINGARD.

(Deprecatingly.)

Oh, no ----

(sHE looks furtively about, as though expecting some one)

\section{LORD USKE.}

How often I have envied some insignificant fellow like that Captain. [sic] Dullaston who was hanging about you at luncheon! One of those coarsegrained natures that never feel a rebuff. Ha! ha!' ${ }^{12}$ the thick-skinned idiot! I don't suppose it ever occurs to him that he may be boring a woman to death. My weak point is over-sensitiveness. I can't bear to remain a moment where I fancy I am not welcome.

\section{(Tenderly)}

Let us sit down here away from all the others. 
I'm afraid I ought to be going.

(She looks around again)

\section{LORD USKE.}

So soon?

\section{(Looks at watch)}

We have not been together more than two hours and three quarters---and so much remains unsaid!

\section{(MRS LINGARD sighs)}

Think of the moral solitude to which we both return! Don't you dread the mockery of your home life?

MRS. LINGARD.

\section{(Absently)}

Oh, yes.

\section{LORD USKE.}

The poetry of the hearth is what I have always craved.

(Significantly)

I believe there is the same lack of it in your environment.

MRS. LINGARD.

\section{(Looking down)}

George is so much engrossed in his profession.

$$
\text { LORD. [Sic] USKE. }
$$

The civil service ---a most prosaic one.

MRS. LINGARD.

He has great hopes of being promoted this year. I have always wished for him --- 
LORD USKE.

The opportunity to travel?

MRS. LINGARD.

Oh, yes!

LORD USKE.

(Warmly)

I shall be glad to be of any assistance. How would the Gold Coast do?

MRS. LINGARD.

(Repressing her eagerness)

Isn't the climate ----rather bad?

LORD USKE.

For women only. No wives are ever taken.

(He takes her hand)

I shall do all I can to press your husband's case.

MRS. LINGARD.

Oh, thank you.

(Withdrawing her hand)

I'm really afraid I must go.

LORD USKE.

Let us leave together, then. I'll drive back to town with you.

MRS. LINGARD.

\section{(Embarrassed)}

Oh ---but I'm afraid you mustn't.

$$
?[\text { Sic] LORD USKE. }
$$

(Heroically)

How little you know me! I would risk far more for your sake! 
(CAPTAIN DULLASTON, a good looking bored young man, saunters in from the left. Mrs. LINGARD catches sight of him over Lord Uske's shoulder.)

MRS. LINGARD.

(Hurriedly, to Lord Uske)

Then --- will you please have my carriage called?

LORD USKE.

(With an assumption of youthful activity.)

At once!

(seeing her smile and nod over her shoulder)

Who's there?

MRS. LINGARD.

(Reluctantly)

Captain Dullaston.

LORD USKE.

Again?

(Reassuringly)

Never fear! I'll come to your rescue in a moment.

(Hastens stiffly away)

CAPT. DULLASTON.

(Approaching Mrs. Lingard)

This is simply preposterous! I haven't had two words with you.

MRS. LINGARD.

What can I do? He's so kind to George!

\section{CAPT. DULLASTON.}

The thick-skinned idiot! I don't suppose it ever occurs to him that he may be boring a woman to death.

(THEY go out together) 
MAZARET.

(Coming forward and writing on his cuff.)

Eighteen.

CLODAGH.

Why do you do that?

MAZARET.

(Glancing toward the house)

Because I see the eighteenth interrupting ${ }^{13}$ approaching.

(A FOOTMAn comes out of the house, descends the terrace steps, and hands a note to Clodagh.)

FOOTMAN.

An Answer, Miss.

MAZARET.

(Taking a note-case from his pocket and offering it to Clodagh with his pencil) Can't you write here?

CLODAGH.

(wHo [sic] has turned pale as she opens the note.)

I --- no --- that is --- thanks; but I must go myself ---

MAZARET.

(Looking at her intently)

Go? Where?

\section{CLODAGH.}

(Confused)

To --- just to send the answer.

(To the footman)

Say 'yes', please.

(The footman goes out and she turns again to Mazaret.)

Will you wait for me here? 
MAZARET.

(Pointedly)

You wish me to?

\section{CLODAGH.}

(Earnestly)

Yes.

(He makes a gesture of consent and she hastens into the house.)

MAZARET.

(Looking after her, with his hands in his pockets)

The deuce!

(He starts after her and then turns back.)

No!

(HE walks up and down uneasily)

The deuce!

(With a sudden inspiration)

Ah --- Mr. Derwent!

(Hurries out in the direction which Kate and Lady Uske have taken.)

(The stage is empty a moment; then LADY USKE and LORD OSTERLEIGH come out of the house and descend the terrace steps.)

LORD OSTERLEIGH.

(Impatiently)

Well?

\section{LADY USKE.}

Nothing ---absolutely nothing.

(He makes a gesture of incredulity)

Let us sit down a moment. Kate is saying goodbye to the last people and we shan't be interrupted here.

(They sit down under the trees.)

\section{LORD OSTERLEIGH.}

You've been down there ---? 


\section{LADY USKE.}

Last Monday. I invited myself down to the vicarage --I think I told you the vicar had married my aunt ---and I spent two days there. Every one in the place knew Miss Tredennis, and, my aunt took me to call on her people. The brother is a civil engineer.

\section{LORD OSTERLEIGH.}

Well?

\section{LADY UKSE.}

Well --- he certainly was very civil.

(Deprecatingly)

There --- I won't do it again!

(In a more serious tone)

The other sisters live with him and his wife. They were very much pleased by my visit and "ventured to ask me to dine." The dinner hour was two, but I ventured to go --- there's nothing I wouldn't do for you Osterleigh! I was never in an atmosphere of more oppressive respectability. They all had on their Sunday clothes, and the dinner was --Oh, well, the kind that grace is said over; it never is, you know, over really good food. They talked a great deal about Kate ---told me all her past history---didn't fight the least shy of the subject--- nothing to be found out there!

\section{LORD OSTERLEIGH.}

Oh ---her own people!

\section{LADY USKE.}

Then I canvassed the village. Same result. Every one had a good word for her; and they all agreed in thinking it odd that a girl who had made such a brilliant match should never have received any attention in her own town. Her sister Lucy, now, was very much admired; but nobody had ever looked at Kate. She was too clever and hadn't enough color --that was the general verdict.

(A PAUSE)

If there is anything, it must have happened after she left home. 


\section{LORD OSTERLEIGH}

She went to live with Agnes after a year in the hospital; and while she was in hospital----

LADY USKE.

You've enquired?

\section{LORD OSTERLEIGH.}

\section{(Shrugging his shoulders)}

Nothing.

\section{LADY USKE.}

Then we've all been utterly mistaken.

\section{LORD OSTERLEIGH.}

(Musing.)

Unless --- unless there was something while she was at Winterby.

\section{LADY USKE.}

$\underline{\text { (Startled) }}$

At Winterby? Good heavens. You don't mean?

\section{LORD OSTERLEIGH.}

Derwent? Oh, no. While Agnes lived he had no eye for any other woman. But the other day it occurred to me ---

\section{LADY USKE.}

\section{(In suspense.)}

Well?

\section{LORD OSTERLEIGH.}

Straws show which way the wind blows, and --- Well, when Mrs. Derwent was talking over this little party the other day, and asking me whom she should invite --- you know that way she has of always affecting to consider my wishes and follow my advice --- I happened to suggest her asking Basil Mount. 


\section{LADY USKE.}

Basil Mount?

\section{LORD OSTERLEIGH.}

Most natural suggestion. One of Derwent's oldest friends, as you know; he was always down at Winterby before Agnes's death.

LADY USKE.

Well?

\section{LORD OSTERLEIGH.}

Well --- she refused point-blank.

\section{LADY USKE.}

\section{(Struck)}

H'm ---What reason did she give?

\section{LORD OSTERLEIGH.}

None. She blushed and stammered, and then pulled herself together and said of course any one I wished was welcome, and the note should go at once.

\section{LADY USKE.}

Did it?

\section{LORD OSTERLEIGH.}

I don't know. He’s not here, as you see.

\section{LADY USKE.}

And from her behaviour you infer ---?

\section{LORD OSTERLEIGH.}

Hang it, they must have had plenty of opportunity of seeing each other at Winterby; and you know Mount is considered fatal to the women. 


\section{LADY USKE.}

(Musing)

Yes --- I've heard so.

(After a retrospective pause.)

But in this case I believe you're mistaken.

LORD OSTERLEIGH.

(Irritably)

Why?

LADY USKE.

I don't know --- but it's not that.

LORD OSTERLEIGH.

\section{(Obstinately)}

Then it's something else.

LADY USKE.

But what can it be?

\section{LORD OSTERLEIGH.}

God knows! But it's making John miserable.

LADY USKE.

Oh ---

\section{LORD OSTERLEIGH.}

I can't be deceived. You know as well as I do, Susan, that their happiness is too ---too vivid to be genuine.

\section{LADY USKE.}

It does look like the kind that washes off at night.

\section{LORD OSTERLEIGH.}


They're always remembering to be happy; and the real thing is as unconscious as breathing!

\section{LADY USKE.}

But if John knows something and has made up his mind to conceal it, oughtn't you to respect his decision?

\section{LORD OSTERLEIGH.}

And leave Agnes's child to grow up under the care of a woman I distrust? No ---no! I have Sylvia's rights ${ }^{14}$ to defend ---a sacred charge and one I shall never relinquish. Derwent has always been weak where women are concerned. His marriage was an act of madness --- a wild impulse of gratitude to the woman who had nursed Agnes. If he's too proud to own his mistake, I shall not stand by to see Sylvia sacrificed and his career ruined by such a false sense of dignity. Yes, ruined, I say! The man has lost all heart, all ambition. His chief has spoken to me about him several times lately.

(Rises and walks up and down agitatedly)

If I could only get him away for a while.--- if he could be sent off on some special mission, and detached from this woman's influence --- I suggested something of the sort the other day at the Foreign Office.

\section{LADY USKE.}

Hush! Here they come.

\section{LORD OSTERLEIGH.}

Let us stroll down the river.

(They go out)

(KATE AND DERWENT come out of the house and come down toward the front of the stage)

\section{DERWENT.}

This is the first chance I've had to speak to you.

\section{KATE.}

(Constrained) 
I thought you would be glad to see a few of your friends. Was I wrong in asking them?

\title{
DERWENT
}

Of course not. I like you to amuse yourself--- to have a cheerful house.

\author{
(A Pause)
}

But this is our wedding-day. . .

KATE.

(Embarrassed.- [sic]

Yes?

\section{DERWENT.}

And I haven't had a chance to give you this little trifle that I brought down from town with me.

(He holds out a small morocco box.)

KATE.

Oh, how good you are!

(sHE opens it and discovers a string of pearls)

How beautiful!

\section{DERWENT.}

\section{(In a constrained tone)}

I notice you sometimes wear the sapphires I gave you when we were married.

\section{(A Pause)}

They have painful associations for us both. Will you --- put them away --- to please me---and wear these instead.

KATE.

Oh ---.

(sHE closes the box and stands silent; then she breaks out)

Ah, you've never believed me! 


\section{DERWENT.}

(Startled and embarrassed)

Kate!

KATE.

\section{(Passionately)}

Never --- never --- never ---in your heart of hearts!

\section{DERWENT.}

You are cruelly unjust.

KATE.

Oh, I'm human, that's all!

\section{DERWENT.}

\section{(Trying to take her hand.)}

Hasn't my conduct shown in the last year---?

KATE.

It's shown that you're too proud to let any one know what you're suffering. Oh, I never meant to speak out like this, but I --- I can't keep silent any longer. I know how noble, how generous you've been ---but I care for you too much to live on your generosity. What I want is your love!

\section{DERWENT.}

\section{(Very gently)}

Isn't this a mistake, dear? You are agitated--- over-tired. I'm sorry I spoke of the sapphires.

KATE.

(Wildly.)

Oh, don't you suppose I see them every time I look in your eyes [sic] 
DERWENT.

Hush! Here comes Lord Osterleigh and Lady Uske. I'll take them round by the tennis-court.

(He hastens out to the left)

(KATE sinks into a chair and hides her face. In a moment MaZARET [sic] comes out of the house, glances about, and hurries toward her.)

MAZARET.

Mrs. Derwent! I've been looking everywhere for you.

(Kate composes herself and tries to smile.)

Now that everyone has gone may I say a word to you?

KATE.

How serious you are!

MAZARET.

(With an attempt at gaiety.)

Yes ---looks like a borrowed hat on me, doesn't it?

(He sits down beside her and speaks in rapid earnest undertone)

Mrs. Derwent, when Clodagh accpeted [sic] me I was the happiest man on earth.

KATE.

The past tense already?

MAZARET.

Yes!

(He leans forward.)

Something extraordinary has come over her. Oh, I can't be mistaken [sic] She's hiding something from me.

KATE.

Hiding ---?

MAZARET.

Yes ---. She --- she --- goes to meet a man --- who sends for her --- 
KATE.

Clodagh? You're dreaming!

MAZARET.

(Abruptly)

I tell you he's here to-day.

KATE.

(Pale, startled)

Here?

MAZARET.

He sent for her not twenty minutes ago.

KATE.

How do you know?

MAZARET.

Because I followed her. She --- she told me to wait for her here, and I mean [sic] to $^{15}$, I swear. But I went to look for you, to ask you what it could mean, and when I couldn't find you, I ---I walked toward the gate, and saw her going down the road toward the King's Arms.

KATE.

Mr. Mazaret!

MAZARET.

Oh, hang it, you know, when you see a girl walking off with your happiness in her pocket, haven't you a right to go and see what she's going to do with it?

KATE.

Well? ---? [sic]

\section{MAZARET.}

At the door of the King's Arms a man was waiting for her. She talked with him a few minutes and then handed him something. 


\section{(a Pause) [sic]}

I've seen her with the sam [sic] man before ---I saw them in Kensington

Gardens, one day last omnth [sic] when she'd sent me word that she was ill and could'nt [sic] see me.

\section{KATE}

\section{(In a low choking voice)}

It's impossible! You must be mistaken.

MAZARET.

(Excitedly)

Mistaken? I'd know the man anywhere --- a tall black theatrical-looking fellow, with a kind of seedy good-looks---

\section{(KATE starts uncontrollably)}

What's the matter? You look ill.

KATE.

No --- no; but what you say is so strange---

(She looks about her apprehensively)

What became of the man?

MAZARET.

$\mathrm{Oh}$, he disappeared in the direction of the station.

KATE.

And Clodagh?

\section{MAZARET}

She came back and I saw her go upstairs. Shed been crying.

KATE.

(After a pause, in a low strained voice)

And what do you --- suspect? 


\section{MAZARET}

I wish to heaven I knew!

MAKE [sic]

Mr. Mazaret--

MAZARET

Yes?

KATE

Do you remember one day last spring when we were all talking about Sir Gerald Willoughby's marriage?

\section{MAZARET}

Sir Gerald Willoughby's --? Stop a moment! Yes; to be sure I do. It was the first day that Clodagh gave me the least encouragement.

(Thoughtfully)

She showed it by not letting me see her home.

KATE

Do you remember what you said? That if circumstances were against your wife you'd distrust circumstances and not her?

\section{MAZARET}

There's nothing a man won't say when he's in love!

KATE

Aren't you in love now?

\section{MAZARET}

I'm engaged.

\section{KATE}

Is there such a difference? 


\section{MAZARET}

All the difference between theory and practice.

KATE

(After a pause, speaking with an intense effort)

And if I were to tell you that I think I know Clodagh's motive - and that - that it does her honor?

\section{MAZARET}

(Startled)

You know---?

\section{KATE}

If I were to tell you that the secret is not hers -- that what she does is done to shield a friend--? Mr. Mazaret, if I were to assure you of this, would you be satisfied to ask no more?

\section{MAZARET.}

\section{(After a pause)}

My dear Mrs. Derwent, if you were to tell me this, I should profess myself satisfied and go home and be perfectly miserable.

KATE.

(Bitterly)

Ah---I know what you mean.

(CLODAGH comes out of the house unperceived by them)

\section{CLODAGH.}

(From the terrace)

Kate! Kate!

\section{MAZARET.}

\section{(Nervously)}

There she is. I --- I'm going. I can't see her noe [sic]. I'm going back to town.

(He catches up his hat) 
KATE.

(With sudden authority)

No; wait.

(She walks to the terrace steps and calls)

Clodagh! come down!

(CLODAGH comes slowly down the steps. SHE is pale and her face shows traces of recent agitation. She avoids Mazaret's eye)

KATE.

(Taking her hand)

Clodagh --Whom did you go out to meet just now?

\section{CLODAGH.}

(Starting and withdrawing her hands)

I? --I went out alone--- for a stroll by the river.

KATE.

Yes; but someone joined you at the King's Arms.

\section{CLODAGH.}

(Turning abruptly to Mazaret)

You followed me?

MAZARET.

(Guiltily)

Yes.

\section{CLODAGH.}

Ah---.

(To Kate)

I decline to answer.

KATE.

\section{(Gently)}

Isn't that a mistake, dear? I think you owe Mr. Mazaret an explanation. 


\section{CLODAGH.}

I'm sorry -- but I can't give it.

MAZARET.

(Entreatingly)

Clodagh---

KATE.

(Stepping between them)

I can, then; for I can guess whom you met' [sic].

\section{CLODAGH.}

$\underline{\text { You? }}$

KATE.

Yes; and I know for whose sake you did it!

(With her arms about Clodagh)

Dear! ${ }^{16}$

\section{CLODAGH.}

(Sobbing)

Oh, Kate -- oh, oh ---

KATE.

(Keeping her arms about Clodagh)

It was for me, Mr. Mazaret.

CLODAGH.

Kate, I forbid you!

MAZARET.

\section{(Overcome)}

You? 


\title{
CLODAGH.
}

You shan't speak, Kate-- you shan't!

KATE.

(Firmly)

Mr. Mazaret has a right to know.

\section{CLODAGH.}

\author{
(Breaking out)
}

But I --- I don't know!

KATE.

You don't ---?

\section{CLODAGH.}

\section{(Pantingly)}

I only know that some danger threatens you --- you and John. It happened by accident, two or three months ago. One day when I was at your house waiting for you to come in, a letter was brought me by mistake -- an unaddressed letter ---

KATE.

(Quietly)

Asking for money?

\section{CLODAGH}

Yes.

KATE.

And you answered it?

\section{CLODAGH.}

I saw that something was troubling you -- I had guessed it long before --- 
KATE.

Ah ---

\section{CLODAGH.}

And so I went and --- and --- met the man --- and gave him what I could ---

MAZARET.

You angel!

KATE.

Without knowing?

\section{CLODAGH.}

I knew I could help. What more does one need to know when one's friends are in trouble?

MAZARET.

Mrs. Derwent, won't you kindly have me kicked'out [sic] of the house?

KATE.

\section{(To Clodagh)}

You have been heroic, dear; but there must be no more concealment.

(With sudden passion)

No more pretending. . .no more feigning a happiness that hurts!

(Controlling herself)

This man you saw -- Dr. Carruthers--?

\section{(Clodagh nods)}

He found out--no matter how--a secret of mine that I would have given my life to keep from John.

(During these words DERWENT has entered unperceived and stands

listening)

I can't tell you what the secret is. I leave you to believe, if you can, that I'm not ashamed of it--- that I kept it from John not for my sake, but for his -- and -and that of others...

\section{(With an effort)}

A year ago John found out..I had to tell him..to save others. . . 


\title{
(Breaking down)
}

Oh, believe the best you can of me! And in judging me, remember that he knows, and that he---

\section{DERWENT.}

(Coming forward and speaking quietly)

Is satisfied.

KATE.

(Starting)

Ah ---

\section{DERWENT.}

What is this, Kate? What has happened?

KATE.

\author{
(Agitated)
}

Clodagh -- that man --

\section{DERWENT.}

The infamous scoundrel! He's been here --- to-day? He's spoken to Clodagh? Taken money from her?

(THEY are all silent)

I guessed as much.

(Taking CLODAGH's hand)

Thank you, Clodagh.

\section{(A pause)}

This shall not happen again. I have made up my mind to have the man arrested. If there is to be any scandal we must face it. But whatever happens, remember, Clodagh -- and you, Mazaret, since you are so soon to be one of us -- that I am in my wife's confidence and that I approve the course she has taken.

(He takes KATE's hand and raises it gravely to his lips)

(LORD OSTERLEIGH and LADY USKE suddenly appear at one of the

French windows opening on the terrace. LORD OSTERLEIGH waves

an open letter in his hand and hastens across the terrace, followed by

LADY USKE.) 


\section{LORD OSTERLEIGH.}

(Excitedly)

Derwent, my dear fellow--

(THEY all look up)

\section{LORD OSTERLEIGH.}

(Descending the terrace steps)

My secretary, Hickson, has just driven down from town with this letter from Lord Ripton, which was sent to my house today at two o'clock, marked "urgent". (Looking at his watch)

Just half-past six. Quick work, by Jove!

\section{DERWENT.}

(Startled)

Lord Ripton?

\section{LORD OSTERLEIGH.}

Will you undertake to start for China tomorrow on a special mission? Here -read -- see what he says. There's no time to be lost. You can catch the P. and O. boat that sails tomorrow morning if you take the last train up tonight. There will be just time to get your instructions on the way through town ---

\section{DERWENT.}

This is -- very sudden ---

\section{LORD OSTERLEIGH.}

Ripton had said nothing to you?

\section{DERWENT.}

He spoke of the possibility -- a day or two ago---

(KATE looks at him intently through the following scene)

--but I had no idea the summons would come so soon.

\section{LORD OSTERLEIGH.}

\section{(Relieved)}

Ah -- then you're not unprepared? 


\section{DERWENT.}

\section{(Hesitating)}

Not quite; [sic] but I haven’t spoken to my wife.

\section{LORD OSTERLEIGH.}

\section{(To Kate)}

Mrs. Derwent, I believe this mission may be a turning-point in your husband's career. Such a brilliant opportunity is seldom offered to so young a man. It would be madness to refuse---

KATE.

(Simply)

The up-train doesn't start for an hour. We'll all help with his packing, I'm sure!

\section{LADY USKE.}

\section{(To Lord Osterleigh)}

Ah, that was brave!

\section{DERWENT.}

(In a low tone, to his wife)

Do you understand that I must go alone? That in the present state of things out there it's quite impossible to take you and Sylvia?

KATE.

\section{(Quietly)}

I understand.

\section{DERWENT.}

That it may mean an absence of a year -- two years --- ?

KATE.

Yes.

\section{DERWENT.}

\section{(Eagerly)}

And you tell me to go? 
KATE.

And I tell you to go.

$$
\text { DERWENT. [SIC] }
$$

(Earnestly)

Thank you.

(Another pause)

KATE.

\section{(Turning to Clodagh)}

Sylvia should be told of this at once. Will you go and call her, dear?

(CLODAGH and MAZARET go toward the house)

\section{LORD OSTERLEIGH.}

Shall I order the carriage, Derwent? Hickson and I will go up to town with you. Clodagh and Lady Uske will of course remain with Mrs. Derwent.

LADY USKE.

(Affectionately, to Kate)

Of course.

LORD. OSTERLEIGH.

(Going up to Kate and speaking in a low tone)

This is -- very generous of you -- my dear.

(He holds out his hand. KATE turns away with an uncontrollable gesture.

He signs to Lady Uske and they go toward the house together. KATE and

DERWENT remain silent for a moment)

KATE.

(In a composed voice)

Hadn't you better tell Wilkins what to pack?

DERWENT.

No -- everything I shall need is in town. I'll take Wilkins up with me and he can do my packing tonight.

(Another pause. воTH are painfully constrained) 
KATE.

(Suddenly)

You expected this?

DERWENT.

I --- Lord Ripton had sounded me -- vaguely -- not long ago---

KATE.

I'm glad you have what you wish.

\section{DERWENT.}

(Constrained)

As Lord Osterleigh says, it may be the stepping-stone to great things. I can hardly afford to refuse it.

(A pause)

That is, unless -- Kate--

(He takes her hand)

(sYlvia comes out of the house and runs down the terrace steps)

SYLVIA.

Father, --oh, father ---it isn't true?

(Throws her arms about him)

DERWENT.

(Moved)

I'm afraid it is, dear.

(Holds her fast, stroking her hair)

SYLVIA.

You're going to leave Kate and me-- going off now-- tonight --- for ever and ever so long?

DERWENT.

It's a very sudden summons, dear. I'm like a soldier, you know. I've got to obey orders. 
SYLVIA.

But you'll take us with you, father?-- Say you will!

KATE.

Soldiers' wives and daughters must obey orders too, you know, Sylvia - Our orders are to stay at home, and be brave and cheerful till your father comes back.

\section{DERWENT.}

(Hesitatingly)

Perhaps you may be able to join me later-- when things are more settled over there ---

SYLVIA.

(Hopefully)

Oh, that'll be jolly, dad. And in the meantime I shall have to take care of mummy -- shan't I?

\section{DERWENT.}

The very best of care.

$\underline{\text { (LORD OSTERLEIGH re-appears }}^{17}$ and comes down the terrace steps,

followed by LADY USKE)

\section{LORD OSTERLEIGH.}

The carriage will be at the door in half an hour. Is there any thing I can do to help you, John?

\section{DERWENT.}

No, thanks. I shall have time to pick up my traps in town tonight.

\section{LORD OSTERLEIGH.}

(To Sylvia)

Ah, Sylvia, dear.

(Kissing her)

Not crying? You mustn't make it harder for your father to go. 
(Smiling bravely)

Oh, no, grand-dad, I don't mean to. Kate and I are going to be as brave and cheerful as anything -- aren't we, father? And I'm to take care of Kate till father comes back.

\section{LORD OSTERLEIGH.}

(To Derwent, drawing him slightly aside)

One word, John. Have you -- er -- made any plans about Sylvia?

\section{DERWENT.}

About Sylvia? Oh, I shall keep on the town-house, of course--- and I caresay [sic] Kate will go abroad for the winter.

\section{LORD OSTERLEIGH.}

And Sylvia?

\section{DERWENT.}

Sylvia---?

(A pause)

\section{LORD OSTERLEIGH.}

Do you intend to leave Sylvia entirely to Mrs. Derwent's care during your absence?

\section{DERWENT.}

\section{(Embarrassed)}

I--- I hope you will consider her in yours as well, sir.

\section{LORD OSTERLEIGH.}

That was what I was about to suggest.

(DERWENT looks up, startled)

That you should give me Sylvia.

\section{DERWENT.}

Take her away from Kate? 


\section{LORD OSTERLEIGH.}

(Rashly)

She is nothing to Mrs. Derwent.

DERWENT.

Nothing?

\section{LORD OSTERLEIGH.}

\section{(In a conciliatory tone)}

There is no relationship, I mean. Sylvia is my daughter's child and I am an old man. She is to be separated from you -- for two years perhaps -- and it seems to me only fitting that during that time she should be in the care of her mother's family.

\section{DERWENT.}

\section{(With increasing hesitation)}

But --if I leave her with Kate -- as I of course intended to do--- surely you two can share the responsibility?

\section{LORD OSTERLEIGH.}

\section{(Decisively)}

Impossible!

\section{DERWENT.}

Impossible?

\section{LORD OSTERLEIGH.}

Forgive my abruptness, my dear John ---

(He lays his hand on Derwent's shoulder)

--and believe that I speak from no ill-will to your wife. In such a case I can consider no one but Sylvia -- and Sylvia is Agnes's child.

\section{DERWENT.}

\section{(Aside)}

Agnes's child! 


\section{LORD OSTERLEIGH.}

It is your duty -- it is my duty -- to ask ourselves to whom her mother would have wished her entrusted.

\section{(A deprecating gesture)}

I know that Mrs. Derwent was Agnes's friend-- but she is a young woman, inexperienced in the ways of the world, unaccustomed to grave responsibilities, with associations, habits, traditions, all as different as possible as those amid which, had Agnes lived, her daughter would have been brought up. Believe me, I am not saying a word against Mrs. Derwent -- I am simply looking at the case as I believe Agnes would have looked at it. Thst [sic] is my first duty--- at such a moment the only one I can see.---

\section{DERWENT.}

\section{(Agitated)}

But Kate would be willing to go to you for counsel -- advice --

\section{LORD OSTERLEIGH.}

Impossible, my dear John, I repeat. A divided responsibility would be intolerable to us and disastrous to Sylvia. A child, at her impressionable age, should be under one person's control. I am sure Mrs. Derwent would agree to that.

\section{DERWENT.}

You make it very hard for me, sir. How can I decide such a question off-hand?

\section{LORD OSTERLEIGH.}

Let Mrs. Derwent decide it.

\section{DERWENT.}

Kate? Do you mean -- now?

\section{LORD OSTERLEIGH.}

You can hardly leave England with your daughter's fate unsettled.

(He goes toward Kate, who is talking with Lady Uske and Sylvia)

Mrs. Derwent -- I want your help.

(He draws her away from the others) 
KATE.

My help?

\section{LORD OSTERLEIGH.}

I want you to ask your husband to leave Sylvia with me till his return.

KATE.

(Startled)

Sylvia?

\section{LORD OSTERLEIGH.}

Yes.-- I am an old man, remember, and she is my daughter's child. Isn't it natural that I should wish to keep her?

(A pause)

I plead for her in Agnes's name. I put it to you, Mrs. Derwent --- you who may some day have a daughter of your own -- isn't it a mother's instinct to entrust her child to her own flesh and blood?

(There is a long silence)

KATE.

(Taking no notice of Lord Osterleigh, but turning slowly to Derwent)

Is this your wish?

\section{DERWENT.}

(Embarrassed)

It's all so sudden--- I had no idea that Lord Osterleigh---

\section{LORD OSTERLEIGH.}

\section{(Urgently)}

It depends on you, Mrs. Derwent. Derwent is afraid you may feel hurt -- may think yourself slighted -- he doesn't dare plead my cause and so I appeal to you.

KATE.

\section{(To Lord Osterleigh)}

You wish Sylvia to be entirely under your care -- to live with you, in fact? 
(LORD OSTERLEIGH makes a gesture of assent)

You wish to separate her from me?

\section{LORD OSTERLEIGH.}

\section{(Deprecatingly)}

You are so young, fond of society, your life is full of interests and amusements -I am old, tired and lonely. There are times when the care of a girl of Sylvia's age might be a burden to you, a restriction -- while to me it could be only a joy and a consolation.

KATE.

I see - and you propose to relieve me of the burden -- to relieve me completely?

\section{LORD OSTERLEIGH.}

\section{(Deprecatingly)}

I have already pointed out to Derwent how injudicious it is to divide the responsibility in such cases. It can only make the child unhappy.

\section{(Persuasively)}

You agree with me in that respect, Mrs. Derwent?

KATE.

Yes.

\section{LORD OSTERLEIGH.}

I was sure you would.

(To Derwent)

Your wife is always so reasonable.

(To Kate)

I have your consent, then?

KATE.

\section{(After an interval)}

I have nothing to say. My husband must decide.

\section{DERWENT.}

\section{(Earnestly, going up to her)}

Kate -- I entreat you to not make this more difficult for me! 
KATE.

(Bitterly)

More difficult---?

DERWENT.

(In a low tone)

You must remember that Sylvia is Lord Osterleigh's granddaughter---

KATE.

(In the same tone)

And Agnes's child!

DERWENT.

Ah--you are cruel.

KATE.

(Slowly)

Cruel -- am I cruel? I don't mean to be -- for you were very generous to me. . .just now. . .

\section{(A pause)}

Give'me [sic] a moment, please -

\section{DERWENT.}

\section{(Weakening)}

Kate---!

KATE.

(To Sylvia, who has been talking with Lady Uske)

Sylvia!

SYLVIA.

(Running to her affectionately)

Mamma! 
KATE.

(Kissing her, and speaking in an admonitory whisper)

Kate, dear---!

(Aloud)

Run off now, and see that Wilkins has everything ready for your father.

(Draws her to her again and kisses her passionately)

Brave and cheerful, dear, remember --brave and cheerful!

SYLVIA.

Yes, mamma ---Kate -- I'll remember!

(She hurries into the house accompanied by LADY USKE)

(KATE approaches Lord Osterleigh and Derwent)

KATE.

I have said goodbye to your granddaughter, Lord Osterleigh.

\section{LORD OSTERLEIGH.}

What? So soon?

KATE.

(In a hard tone)

I rather wanted to get it over.

LORD OSTERLEIGH.

My dear Mrs. Derwent -- I -- I had no idea of --- of ---

\section{DERWENT.}

\section{(Agitated)(Remorseful) [sic]}

Kate -- I -- you mustn't think I meant---you understand that I wished the decision left to you---

KATE.

(On a numb tone)

Oh, yes. You've been very generous. 
DERWENT.

How coldly you say it! I---

(The FOOTMAN appears and speaks to Lord Osterleigh)

LORD OSTERLEIGH.

Derwent, the carriage is here. I'm afraid we've only just time. I'll go and collect my traps. Mrs. Derwent -- I -- I shall see you very soon -- and thank you --

(HE hastens into the house)

\section{DERWENT.}

(Miserably)

Kate---Oh, Kate -- say you forgive me!

KATE.

(Very sadly)

I love you -- that's so much simpler.

DERWENT.

Ah--

(He puts his arms out, but SHE draws back and his kiss falls on her averted cheek)

(With sudden passion)

Kate!

(LORD OSTERLEIGH're-appears [sic] at the window of the house)

\section{LORD OSTERLEIGH.}

\section{(Calling)}

Derwent -- Derwent -- we shall miss our train!

(DERWENT for a moment stands gazing at his wife, but as he moves

toward her she pushes him gently in the direction of the steps, and with a last uncertain glance he hurries away. As he and Lord Osterleigh disappear[sic] KATE stands for a moment looking after them; then she raises her hands to her temples with a laugh.) 
KATE.

A daughter of my own!

(She sinks into a chair and sits staring before her)

How glad he is to go!

(She sits listening intently. In a moment or two carriage wheels are heard retreating over the gravel.)

How glad he is to go!

$-:-\underline{\underline{\text { CURTAIN }}}-:^{18}$ 


\section{-:- THE SHADOW OF A DOUBT -:-}

ACT III. 


\section{$-:-\underline{\underline{A C T} \text { III }}-:-$}

SCENE I: A small neat room in a respectable lodging-house at the East End. Outside, the grey light of a foggy winter day. The room contains a narrow bedstead, a table and two chairs, a dressing-gown and other feminine garments hanging on pegs against the wall, and a spirit-lamp and two cups on a low stand near the grate, which is empty.

As the curtain rises, GWENDOLINE JANE, a small pallid slavey, enters, with a tea-kettle and two letters. She lays the letters on the table, lights the spirit-lamp, puts the kettle on it, and begins a desultory dusting of the scanty furniture. The door opens and KATE DERWENT enters. She wears the plain gown, long cloak, and Quaker-like bonnet and veil of a professional nurse. She has grown thinner, and her face is pale, but her manner is cheerful and decided.

KATE.

Well, Gwenny ---is the water boiling? I'm half-frozen.

\section{GWENDOLINE}

Will be in a minute, nurse. I've just been and lit it. But the room's 'orribly cold. Let me fetch up a bit of coal -- now do, nurse! 'E'll never notice.

KATE.

He? Who?

\section{GWENDOLINE.}

(Guiltily)

That Huniversal Sentiment gentleman wot's in the two pair back.

KATE.

Gwenny! You unprincipled [sic] infant! You haven't been keeping me warm at the expense of the philanthropist downstairs? 


\title{
GWENDOLINE.
}

Wot's the odds? 'E's always carryin' coal to hunfortunates -- ain't respectable people to 'ave any?

KATE.

Not till they've proved their inability to remain respectable without it.

(Going up to the kettle)

But a good cup of tea is better than any fire.

(She makes the tea and pours out two cups)

Here, Gwenny --- you look a little pinched yourself.

(Hands her a cup.)

\section{GWENDOLINE.}

(Taking it.)

Oh, thank you, nurse -- thank you, nurse -- but really, I 'adn't oughter ---

KATE.

\section{(Cheerfully)}

Oh, then you'll enjoy it all the more, you know!

(She tosses aside her bonnet and sits down to drink her tea.)

\section{GWENDOLINE.}

(Who has swallowed hers at a gulp, wiping her mouth with the back of her hand)

'Ere's two letters for you, nurse.

KATE

\author{
(Looking up)
}

Ah --- give them to me!

(GWENDOLINE hands her the letters, and she looks at them and then lays them down with a sigh)

GWENDOLINE.

And there was a lydy 'ere too, nurse, arskin' after you. 
KATE.

A lady? What sort of a lady?

\section{GWENDOLINE.}

(Disconcerted by the necessity of defining)

Well, not the young lydy that comes 'ere sometimes, you know, nurse; it worn't $\underline{\mathrm{er}}$, but it wor the syme kind of a lydy -- you know what I mean, nurse -- the kind that's above bein' 'igh and mighty.

KATE.

And this lady asked for me - for nurse Marchant?

\section{GWENDOLINE.}

That's 'oo she arst for. And she said as 'ow she'd come back presently.

KATE.

A case at last, perhaps -- who knows, Gwenny? Well, run off now, child -- and you'll find me here if the lady comes back.

\section{GWENDOLINE.}

All right, nurse.

(She goes out with an affectionate glance at KATE, who looks after her wistfully)

KATE.

\section{(Sighing, as the door closes)}

It's only the children who believe in me ----.

(She opens her letters, and glances over the first.)

--- "Lack of satisfactory references -- regret that there is no opening at present --any responsible person who could vouch for you ---" the same old story.

(Opens second letter)

"Dearest Mummy, Clodagh has promised to send you this letter, and so I write to tell you how I miss you. Oh, Mummy, why don't you come back to us?”

(Putting it hurriedly aside) 
Ah, I can't bear it!

'[sic] Leans on the table, hiding her face in her hands.)

(The door opens and GWENDOLINE puts in her head)

GWENDOLINE.

'Ere's the lydy, nurse.

(She draws back.)

(KATE starts up as LADY USKE enters the room.)

KATE.

Lady Uske!

LADY USKE.

It's taken me nearly a year and cost me a perfect fortune.

(Sinks breathlessly into a chair)

What a goose you are, and how this place smells of cabbage!

KATE.

Was it Clodagh who told you?

\section{LADY USKE.}

No indeed, I wish she had! It would have been infinitely cheaper.

KATE.

Cheaper?

LADY USKE.

Than Scotland Yard.

KATE.

Scotland Yard? Lady Uske!

\section{LADY USKE.}

If people won't put their names in the Red Book their friends have to pay for it! 
KATE.

(Coldly)

I cannot imagine why you should have been at such expense on my account.

\section{LADY USKE.}

Oh, it isn't on your account -- it's on mine! I did you an injustice once -- and -and I've been trying to apologize for it ever since.

KATE.

An injustice?

LADY USKE.

Yes. ---I ---

KATE.

Oh, you needn't explain it! But what makes you think it was an injustice?

\section{LADY USKE.}

The way you've behaved ever since. Oh, don't tell me, my dear! A woman who has something to hide doesn't creep away without a word from her husband's house and bury herself in the slums -- not she! If thered been anything wrong you would simply have remained at home, and engaged the best cook in London ---.

KATE.

\section{(Smiling)}

And my not doing so----?

\section{LADY USKE.}

Has shown me what a fool I am, in spite of --- well, some years experience --to forget it's only the perfectly innocent who dare to act as if they were guilty.

(Holds out her hand)

Will you accept my apology?

KATE.

Willingly, but I hardly think it was your only reason for coming here to-day. 


\section{LADY USKE.}

You're quite right; I came to preach as well as to do penance.

(Seats herself near the tea-table)

Do you know that this room is horribly cold? Won't you give me a cup of tea?

KATE.

\section{(Embarrassed [sic]}

I’m so sorry --- but ---

\section{LADY USKE.}

There isn't any left?

\section{(Earnestly)}

Mrs. Derwent, you've no business to be freezing and starving yourself like this. For whose benefit are you doing it? Oh, don't imagine that I'm trying to pry into your secrets. I'm inquisitive about my acquaintances, but I respect the privacy of my friends. I don't want to know why you left your husband; I only want to remind you that we're better judges of the impulses we resist than of those we act upon.

\section{KATE.}

\section{(After a pause)}

I'm sure you mean kindly, Lady Uske -- but believe me, though I left my husband's house so suddenly, I acted on no rash impulse --- and it was he who went first.

\section{LADY USKE.}

Oh, we all know there has been a misunderstanding of some sort between you -- but then, do two people ever really understand each other? I'm sure a lot of positive happiness is missed in looking for the superlative.

\section{(Rising from her seat and laying her hand on Kate's shoulder)}

Come home, my dear. Let people see that you're not ashamed to live under your husband's roof. By-and-bye he'll come back and live there with you, and things will arrange themselves. No matter what's going on at the back of the house, one can always keep flowers in the front windows! 
KATE.

And is it so much easier to pretend a happiness than to accept a grief?

\section{LADY USKE.}

My dear, after twenty, all life is pretending, and it's easier to pretend in a good house, with everybody's cards on the hall table, than alone in a garret under a false name!

KATE.

Ah, but there's one thing I don't have to pretend here -

\section{LADY USKE.}

What's that?

KATE.

That I've forgotten what life was like before I was twenty!

\section{LADY USKE.}

(Struck)-

Oh --- ah --- well ---. You know what the martyrs were? Simply people who refused to forget.

(She goes up to Kate suddenly)

May I kiss you?

(She gathers up her cloak and muff)

Good-bye.

(At the door.)

But you'll have pneumonia, you know!

(Goes out)

(KATE stands looking after her for a while)

KATE.

(Shrugging her shoulders) 
That would be one way out of it.

(With decision)

But not my way -- I'd sooner steal the philanthropist's coal!

(There is a knock on the door)

Who's there?

(She opens it and CLODAGH enters)

Oh, darling!

(THEY kiss each other.)

\section{CLODAFG [SIC]}

I met Lady Uske on the doorstep. How did she find you out?

KATE.

(Smiling)

Never mind. What did she say?

\section{CLODAGH}

Nothing. She just brushed past me with her veil down. I never saw her behave so oddly.

(A pause)

Kate --- did my uncle send her?

KATE.

Oh, no, I think not. She merely came to give me some good advice on her own account. Of course [sic] she'll tell him where to find me! but he isn't likely to make use of the information.

\section{CLODAGH.}

She wants you to return home?

KATE.

\section{(Impatiently)}

Of course! 


\section{CLODAGH}

\section{(Entreatingly)}

If only you would, Kate!

\section{KATE.}

\section{(Holding up an admonitory finger)}

Come, come -- you remember our compact? I shall begin to think it was you who gave my address to Lady Uske!

\section{CLODAGH}

You know I wouldn't do that!

KATE.

Of course not, you dear! And now sit down and let me make you a nice cup of tea. Do you know, I fancied you might come to-day, and I saved my last spoonful of tea for you ---

(She opens a small caddy and looks into it)

I actually pretended to Lady Uske that I hadn't any! But then she says all life is pretending.

(She lights the spirit-lamp and puts the kettle on)

\section{CLODAGH}

Your last spoonful of tea ----?

KATE.

(Hurriedly)

Oh, the last I have in the house, I mean.

(Embarrassed)

The fact is, I forgot to buy any when I was out to-day.

\section{CLODAGH.}

Kate -- you're pretending now! You look thin and pale, and there's no fire in the grate. Haven't you had any work since I saw you? 
Well -- nothing very important ---

\section{CLODAGH.}

And that was a month ago, and you assured me then that you were just about to be engaged on a typhoid fever case!

KATE.

So I was -- but the patient inconsdierately [sic] recovered; and since then nothing has turned up. You see it's an exceptionally healthy season - nobody's dying but the nurses!

\section{CLODAGH}

Kate, you've no right to go on in this way. If you won't accept money from John, or ---- or from Lord Osterleigh --

(KATE makes a gesture of repudiation)

--at least you might let me help you in your work. You know very well that if you would let me recommend you I could find you a good engagement at once.

KATE.

I know, dear, and I'm not ungrateful. But if I were to mention you as a reference it would at once start enquiries about my past. You would find yourself obliged to reveal my real name, and then people would know that John Derwent's wife is in want. I couldn't remain in his house, or accept money from him, but I don't wish to do anything that reflects on his generosity, and it is for that reason that I've chosen to take up my new life under a new name.

\section{CLODAGH}

But if you fail ---

KATE.

I haven't failed yet. Just now my funds are a little low, I admit; but I promise you that I'll call on you for help whenever I really need it.

\section{CLODAGH}

I wish I could believe you! 
KATE.

\section{(Reproachfully)}

Now, then, remember your promise. When you come to see me you're only to talk about the things I'm interested in.

\section{(Hands her the cup of tea)}

And you've been here quite ten minutes and haven't said a word about Sylvia.

\section{CLODAGH}

Sylvia is well. You had her letter.

KATE.

(Nods without speaking, then, after a pause:)

I couldn't read it ---. Don't let her, Clodagh -- again -- it --- hurts too much --- ah! (She hides her face a moment.)

\section{CLODAGH}

Oh, Kate, if only you'd come back to your own house!

\section{KATE}

And live there without her? It was my first night there after she'd gone that decided me. Oh, that empty house -- the very walls seemed to mack [sic] at me! It's awful -- awful -- to live on in the shell of an extinct happiness! --- No, I'm less far from her here.

\section{CLODAGH}

You know what John wishes.

KATE.

Does he wish me to have Sylvia back?

(CLODAGH is silent)

What do I care for his house and his money and his name, if he won't trust me with his daughter? ---- In that one moment the truth was revealed to me. For a whole year he had tried to pretend that he believed in me --- had even tried to deceive himself into believing --- but when it came to leaving Sylvia with me ---! 


\section{CLODAGH}

You must remember that he had Lord Osterleigh to consider.

KATE.

Would that have weighed with him a moment if he had trusted me?----

\section{CLODAGH}

I don't yet know what parted you; but even if he was in the wrong you are punishing him very cruelly. He has written again begging me to urge you to go back to his house - to appear in the world as his wife.

(Pleadingly)

You must admit that his one endeavour has been to shield you--- to put you in the right light with the world.

KATE.

(Passionately)

The world -- the world -- even you, Sylvia! $!^{19}$-- What do I care for your world? I wasn't born into it, I have no claim on it, and I owe it nothing but misery! ---

(Rising and walking excitedly about the room)

What is it, after all -- this world that you're all so afraid of? An idol that you've carved out of your own prejudices and that you all fall down and worship! A monster that feeds on the blood and brains of the wretched beings ${ }^{20}$ who created it! Ah, no --- it's better so, after all. I never could have satisfied your world. I never could have filled my place in it as Agnes did --- I never could have observed its conventions as she did --- I never could have propitiated and wheedled and petted it as she did -- I never could have fawned on it to advance my husband's ambitions, and lied to it -- to make him happy --- as --

\section{CLODAGH}

\section{(Frightened)}

Kate!

KATE.

\section{(Startled, and then rapidly recovering herself)}


I --- ah -- don't mind me, Clodagh.

(Sinks into a chair)

I'm a little out of sorts to-day.

\section{CLODAGH}

You're unjust because you're unhappy -- but you've no right to reject John's offer unheard.

\section{(Entreatingly)}

I wish you would read his letters.

(sHE draws a packet from her muff, KATE makes a vehement gesture of refusal)

Then I wish he'd come back and plead with you himself!

KATE.

Oh, child --- don't you know --- don't you see ---- that to him the whole world's length isn't far enough away from me?

(A KNOCK on the door. GWENDOLINE puts her head in.

GWENDOLINE.

(Excitedly)

Nurse! Nurse! 'Ere's a case at last, I do believe.

(She disappears.)

(Withdraws her head)

(The door opens and LORD OSTERLEIGH enters)

KATE.

(Starting back)

Lord Osterleigh!

CLODAGH.

Uncle!

LORD OSTERLEIGH.

(With ceremonious politeness)

I beg pardon, Mrs. Derwent, for intruding on your privacy --- 
KATE.

(Haughtily)

I can only suppose you have a special reason for doing so.

\section{LORD OSTERLEIGH.}

\section{(Calmly)}

I have.

\section{(He turns to Clodagh)}

My dear, as you are the only one of us who, during the last six months, has had the privilege of Mrs. Derwent's society, I'm sure you won't mind making way for a less favoured visitor?

\section{CLODAGH.}

(Hesitatingly)

Of course, uncle ---

KATE.

(In a low tone, to Coldagh.[sic])

Yes, go, dear; I'd rather have you to myself.

\section{CLODAGH}

Goodbye.

(They kiss)

Goodbye, uncle.

(She goes out. Kate closes the door and stands silent, observing Lord Osterleigh)

\section{LORD OSTERLEIGH.}

(After a pause, during which he has glanced curiously about the room, begins to speak in a quiet voice in which there is a strong reverberation of suppressed excitement.)

You are right in supposing that I should not have forced myself upon you without a sufficient motive. 
(HE looks about hesitatingly for a chair.)

I am still somewhat lame, as you see, and ---

KATE.

(With cold politeness.)

Pray sit down, Lord Osterleigh.

OSTERLEIGH. [Sic]

Thanks.

(He seats himself on one side of the table and she takes a chair on the other.) I have come to tell you that your husband has returned.

KATE.

(Startled)

John?

OSTERLEIGH. [Sic]

He arrived late last night. He was suddenly recalled by the Foreign office and came straight through from Hong Kong. He is at my house at present.

KATE.

(Irresistibly)

With Sylvia!

(Controlling herself at once)

Was it he who sent you here?

\section{LORD OSTERLEIGH.}

Yes. Your conduct since his departure last year has not unnaturally made him hesitate to intrude on you without permission; and I volunteered to take the liberty instead.

(A Pause)

He wished me to tell you of his arrival, and also of the reason for his recall. He has acquitted himself so successfully of his very delicate and complicated 
negotiations in the East that government has summoned him home to offer him the Spanish mission.

KATE.

The Spanish mission!

(Musing)

The one Sir Gerald Willoughby was to have had ---

\section{LORD OSTERLEIGH.}

There was some talk of it's [sic] being offered to Willoughby last year, I believe --but his unfortunate marriage ---

KATE.

Yes ---

\section{LORD OSTERLEIGH.}

Since then no minister has been appointed, but some important diplomatic question has just arisen between the two governments, and it was for this reason that Derwent was recalled.

KATE.

I see. And was he accepted?

\section{LORD OSTERLEIGH.}

He --- er --- the fact is --- his doing so depends on you.

KATE.

On me?

\section{LORD OSTERLEIGH.}

Yes. You must of course know that your leaving him as you did --- leaving his house, at least, and disappearing from the world in which your marriage had placed you, has not escaped --- unfavourable comment --- 
KATE.

Ah.

\section{LORD OSTERLEIGH.}

If you had remained under your husbands [sic] roof the world would have assumed that, whatever grievance he had against you, he intended to give you the protection of his name; and his intention would have been respected. But your abrupt departure from his house --- your sudden and inexplicable disappearance --- your determination to conceal your whereabouts from his family --- all this put another aspect on the case. When a woman refuses to explain her situation to society, society is at liberty to infer what it pleases --- and it always infers the worst. --- Frankly, Mrs Derwent, your conduct has given rise to a great deal of --- unpleasant talk.

KATE.

(Ironically)

As much as Sir Gerald Willoughby's marriage?

\section{LORD OSTERLEIGH.}

\section{(Ignoring her tone.)}

Much more: that was a common enough occurrence; this is a rather unusual one. But the result is virtually the same. Willoughby lost the Spanish legation because he married; Derwent may lose it because he is separated.

KATE.

And I am to be asked to avert this international calamity by returning to my husband's house?

\section{LORD OSTERLEIGH.}

\section{(Slowly)}

No; that is not what I was asked to say to you.

(KATE looks up in surprise)

You know, of course, from Clodagh, that Derwent has repeatedly urged you to go back to his house --- has persistently offered you the protection of his name --- which you have as persistently refused. 
KATE.

Yes.

\section{LORD OSTERLEIGH.}

Doubtless you have had good reasons for doing so. A woman does not leave her husband's roof without some grave provocation on his part --- or some grave fault on hers.

KATE.

\section{(Hastily)}

I have never accused my husband!

\section{LORD OSTERLEIGH.}

\section{(Bowing)}

He emulates your discretion. But since your conduct forces him to regard your decision as final, he can only look about for some other way of adjusting this unfortunate difficulty.

\section{KATE.}

The only difficulty between us was adjusted by leaving him.

\section{LORD OSTERLEIGH.}

From your standpoint, perhaps --- but hardly from his --- or Sylvia's.

KATE.

Sylvia's?

\section{LORD OSTERLEIGH.}

The daughter must inevitably suffer from any cloud on her father's name.

KATE.

Any cloud --- a cloud on John's name?

\section{LORD OSTERLEIGH.}

Remember that you bear it. 
KATE.

Oh!

(After a pause)

But I gave it up when I left him. I am known here by my mother's name --- Marchant.

\section{LORD OSTERLEIGH.}

So I understand; and my object in coming here is to propose that you should ask the law to ratify your --- er --- informal renunciation of your husband's name.

KATE.

(Starting)

A divorce?

\section{LORD OSTERLEIGH.}

It would simply be a way of defining the situation.

(There is a silence)

KATE.

Did John send you here to propose this?

\section{LORD OSTERLEIGH.}

(Slightly embarrassed)

He sent me here to --- to obtain your views --- on the subject.

KATE.

He wishes me to divorce him?

\section{LORD OSTERLEIGH.}

He would of course accord you that advantage.

KATE.

(With intense scorn)

Advantage! 


\title{
LORD OSTERLEIGH.
}

\section{(With sudden quiet brutality)}

Certainly --- since he might divorce you.

KATE.

\author{
(Indignant) \\ $\mathrm{Oh}$ !
}

\section{LORD OSTERLEIGH.}

\section{(Unperturbed)}

A mere hypothesis! As I have said, he accords you all the privileges of the position. He has no wish to cast any reflection on your character.

KATE.

Provided I cast none on his!

\section{LORD OSTERLEIGH.}

(Same tone)

Precisely.

\section{KATE.}

All he asks is that I shall disappear, be effaced, wiped out, cease to exist for him --- is that it?

\section{(LORD OSTERLEIGH bows)}

Then why doesn't my present course suffice? Who would associate the hospital nurse, Kate Marchant, with her Majesty's envoy extraordinary and minister plenipotentiary to the court of Madrid?

\section{LORD OSTERLEIGH.}

No one --- for the present; but --- pardon me for suggesting such a possibility to one of your sex --- suppose some day you change your mind? Suppose you weary of your present life and the fancy takes you to reinstate yourself in the little world you affect to despise? Such things have happened, you know. Women who have quarreled with society at thirty have been glad to make up the quarrel at forty. The first wrinkle sends the penitent to the confessional! 
KATE.

(Haughtily)

I refused to return to my husband when he asked me to; it is improbable that I shall force myself upon him against his wishes.

\section{LORD OSTERLEIGH.}

My dear Mrs. Derwent, I have seen too much of life not to believe in the probability of the improbable.

KATE.

You needn't fear it in this case! Nothing will ever induce me to see my husband again!

\section{LORD OSTERLEIGH.}

Then I fail to see why my proposition ---

KATE.

A divorce? Never! I have relieved him of my presence because I --- I had reason to think --- it --- it was no longer acceptable to him --- but there is nothing in my past to be ashamed of, and I decline to put myself in a false light by consenting to a divorce. -- Will you tell him this, please?

(She rises and looks at Lord Osterleigh as though expecting him to do the same; but he remains seated.)

\section{LORD OSTERLEIGH.}

One moment, please. Is this your last word?

KATE.

Yes.

\section{LORD OSTERLEIGH.}

Then there is no alternative but to say mine.

(With a shrug.)

After all, this interview is not an agreeable one to either of us and it seems a pity to prolong it by beating about the bush. 
(Rising and speaking very deliberately.)

Mrs. Derwent, I am here to ask what you will take to set your husband free.

KATE.

\section{(Suffocated.-)}

Take?

\section{LORD OSTERLEIGH.}

In addition, I mean, to the alimony which the court will, of course allow.

(She stares at him as though not understanding)

What do you say to $\pm 10,000$ ? --- I am ready to place that sum at your disposal this evening.

KATE.

(After a long pause)

Ah --- John didn't tell you to say that!

\section{LORD OSTERLEIGH.}

(Slightly disconcerted)

Er --- he ---; no --- frankly, he didn't.

(Recovering himself)

In fact, I think he relied on your acceding to his request without --- er --- an additional inducement.

KATE.

(Struck)

$\mathrm{Oh}$ !

(Quickly)

He was mistaken, then --- you were both mistaken. Will you go back and tell him so.? [sic]

LORD OSTERLEIGH.

You refuse? 
KATE.

Absoultely.! [sic]

\section{LORD OSTERLEIGH.}

(Tentatively, and hurrying the words out with a brutality intended to conceal his shame at uttering them :)

Twenty thousand ---?

KATE.

Lord Osterleigh!

\section{LORD OSTERLEIGH.}

\section{(Instantly)}

I beg your pardon.

(A pause-)

Mrs. Derwent --- you have always regarded me as an enemy --- but believe me, what I am about to say is the advice of a friend. Don't refuse Derwent's proposition.

(She stands silent, evidently determined not to reopen the discussion) Don't do it.

(An ominous pause)

After all, the divorce court is better than the police court.

KATE.

(With a violent start)

The ---

\section{LORD OSTERLEIGH.}

\section{(With exultant animosity)}

Oh, you understand --- Carruthers has made use of that letter.

\section{KATE.}

Oh! 


\title{
LORD OSTERLEIGH.
}

\section{(Breaking out.)}

I know all --- and if I've spared yoy [sic] --- stooped to argue with you ---persuade you --- bribe you quietly out of our lives --- instead of crushing you at once like the venomous reptile you are ---

KATE

(Shuddering)

Oh --- Oh ---

\section{LORD OSTERLEIGH.}

(Controlling himself)

Mrs. Derwent --- once more --- for Derwent's sake, for Sylvia's I offer you this way of escape.

KATE

(Slowly)

And I refuse it!

\section{LORD OSTERLEIGH.}

(Losing his self-control again)

You --- you refuse? You --- my daughter's ---! Woman, are you blind? Don't you see that you're in my power? That one word from me can destroy you?

KATE.

\section{(Wildly)}

Lord osterleigh [sic], I swear it was out of pity for Agnes --- Sir Hector told me that she could not love ${ }^{21}$---

\section{LORD OSTERLEIGH.}

Bah!

(Warningly)

Let us make an end of this, or I don't answer for myself!

\author{
(A pause)
}

Your decision? 
KATE.

(Hardening instantly)

Remains the same. I am innocent and I refuse to admit myself guilty.

LORD OSTERLEIGH.

Guilty? To whom? Who knows the story but myself and Derwent? The world will think it was some common place quarrel that parted you.

KATE.

\section{(Scornfully)}

The world. Always the world! Don't you see that if I consented my husband would have the right to think me guilty?

\section{LORD OSTERLEIGH.}

(With a contemptuous laugh)

Do you believe him so confident of your innocence?

KATE

No - but he shall see that I am confident of it.

\section{LORD OSTERLEIGH}

\section{(Sneeringly)}

There's not much value in an innocence that can't be proved.

\section{KATE}

No - none; except to its possessor.

\section{LORD OSTERLEIGH}

It remains with you to retain a possession on which you set such store.

\section{KATE}

What do you mean?

\section{LORD OSTERLEIGH}

That if you accept my proposal you can continue to think yourself innocent - on eight hundred a year - whereas if you refuse-- 
KATE

(Breathlessly.)

If I refuse?

\section{LORD OSTERLEIGH}

(Very deliberately.)

My carriage is waiting below. In five minutes I shall be at the police court.

KATE

(With a cry.)

$\mathrm{Ah}$ !

\section{LORD OSTERLEIGH}

(Losing all control of himself.)

Murderess!

(With his hand on the door.)

After all -- I -- I'm glad --

KATE

(Starting forward with an uncontrollable cry.)

Lord Osterleigh--

\section{LORD OSTERLEIGH}

(Turning back, with a savage impatience.)

Well?

KATE

Then - - you mean this?

\section{LORD OSTERLEIGH}

By God -- you shall see!

KATE

(Steadying herself against the table.)

Then - come back - a moment - first - 


\section{LORD OSTERLEIGH}

(Contemptuous.)

More talk?

KATE

No.

(She draws a key from her pocket and unlocks the trunk at the foot of her bed.)

Wait.

(She takes out a leather writing-case, fumbles feverishly for another key, unlocks the case and takes out a folded sheet of paper.)

Ah.

(She moves slowly toward Lord Osterleigh and hands him the paper.)

Will you look at this?

(LORD OSTERLEIGH hunts for his glasses, adjusts them nervously, and looks at the paper.)

Is this your daughter's writing?

LORD OSTERLEIGH

My - - daughters? [sic]

KATE

Answer me, please.

\section{LORD OSTERLEIGH}

(Looking more closely.)

I - yes - I believe so. But in this light --

KATE

(Who has recovered her self-control and now speaks with the same quiet implacableness which marked her manner in the earlier part of the scene.)

I'll light the lamp. 
(She lights a small lamp and puts it on the table, then holds out the paper again to Lord Osterleigh.)

It is your daughter's hand?

\section{LORD OSTERLEIGH}

It - - appears to be - -

KATE

Then read it.

(She puts the paper in his hand.)

\section{LORD OSTERLEIGH}

(Pale and stammering.)

It - - it - - seems a little illegible - -

KATE

Yes. If you'll read it aloud I'll help you -

\section{LORD OSTERLEIGH}

Read it aloud?

\section{KATE}

\section{(With cold determination.)}

Please.

\section{LORD OSTERLEIGH}

(Pulling himself together.)

Certainly.

(He reads.)

"Kate, I want you to look - - look - - in the - - the - -"

KATE

Cabinet.

\section{LORD OSTERLEIGH}

"Cabinet - - over there" - - 
(Breaking off and turning to Kate.)

Will you be good enough to tell me under what circumstances this er - was addressed to you?

\section{KATE}

A few hours before Lady Agnes's death she lost the power of speech.

\section{LORD OSTERLEIGH}

Yes - -

KATE

She was still able to move her right hand and arm - - a little - - and she signed to me to give her paper and pencil - -. It was just after Sir Hector Blair left.

(A pause during which LORD OSTERLEIGH, who has sunk into a chair sits with bowed head, holding the paper in his hand.)

Will you please go on?

\section{LORD OSTERLEIGH}

(With an intense effort.)

"The Cabinet over there - The key is here - Yes, unlock the drawer - the - -"

KATE

(Quietly)

Left drawer.

\section{LORD OSTERLEIGH}

"left drawer - -. Give me the letters quickly. - - Now burn them" (He breaks off.)

Mrs. Derwent - I - - do you insist - - on -- this?

(Kate makes an inexorable movement. He continues to read.)

"And now -- I want you to send word to Basil - - Basil" - -

(HE pauses suddenly, with a flash of terrified retrospection in his face.)

Basil Mount? - - Ah, God! 
(HE bows his head on his hands for a moment. Looking up, he sees KATE standing implacably before him, and renews his reading with a resolute effort at composure.)

"Send word to Basil - about this - - and tell him - tell him - oh, the agony-agony - - . Kate, listen; I knew the truth. Sir Hector told me before he left - - I know it's all up with me. I can't last more than twenty-four hours-- and I want - - want you - - to - - give me something - before John comes. Don't let him see me. If this pain gets worse I may go out of my head -- and say something --. For God's sake, save me from that! Save me for Sylvia's sake - John - - my father - - put me out of this before they come. I'm punished enough - as it is -- this agony -- and the letters - - you're sure - - all burnt? Tell Basil -- oh, the pain ---. Kate! I implore you. We've always been friends don't let me go on like this -- don't let me. I can't stand it - don't let John see me -- like this --"

(HE springs up and crushes the paper in his hand.)

This is not Agnes's writing - this execrable lie -- not --

(HE makes an instinctive gesture as though to tear up the paper.)

\section{KATE}

(Laying her hand quietly on his arm.)

Then why--?

(His arm drops, but he steps back from her, holding the paper out of her reach.)

\section{LORD OSTERLEIGH}

Well, what if it is - anything more than - the cheapest of forgeries. Do you suppose I'd hesitate a moment to protect my daughter by - - by destroying such proof like this?

\section{KATE}

Yes.

(They look at each other in silence for a perceptible interval; KATE erect and relentless, LORD OSTERLEIGH passing from rage to anguish in the speechless struggle with his pride.) 


\section{LORD OSTERLEIGH}

(Moving toward her and holding out the paper.)

Take it, then.

(A pause.)

You're avenged.

(HE hands her the paper)

\section{KATE}

You'll bear witness - it was not vengeance!

\section{LORD OSTERLEIGH}

\section{(Reluctantly)}

No.

KATE

(Breaking down.)

Not till you drove me to it --

LORD OSTERLEIGH

No.

KATE

I - I've paid with my life almost - -

\section{LORD OSTERLEIGH}

Yes.

(The door opens and GWENDOLINE JANE looks in.)

\section{GWENDOLINE}

Nurse! 'Ere's another --

(She disappears.) 
(JOHN DERWENT enters the room. He is pale and agitated. LORD OSTERLEIGH, who has sunk into a chair at the farther end of the room, looks up half-dazed, and DERWENT, hardly noticing him, advance [sic] at once to his wife.)

\section{DERWENT}

Kate! Kate!

(HE moves toward her with an impulsive gesture, but she stands motionless and unresponsive.)

I'm too late?

(HE looks from one to the other.)

No - - at least not too late to be heard! I have that right still, haven't I?

\section{LORD OSTERLEIGH}

(Rising and speaking in a strange shaking voice.)

Derwent--

\section{DERWENT}

(Decisively.)

No - - no. Let me speak. Whatever has been said in [sic] my behalf ---

(He looks steadily at Kate)

I -- am here to unsay it --

KATE

Unsay it?

\section{DERWENT}

Yes - .

(Lord Osterleigh again tries to speak, but DERWENT sternly sings [sic] to him to be silent.)

I - - I came home - after my six months' exile out there -- under those strange skies - I came home feeling it would be impossible for us ever - - to take up life again - - together. I'd shown you once that I didn't believe in you, and you had 
made the only answer a proud woman could make - you had left me. While I was away from you I saw the inevitableness of it all clearly enough. But now-since I've been back -- just these few hours even -- there's a difference - - a difference I can't account for - you seemed to steal back on me in every sound and look of the streets -- I walked past our house this morning and I seemed to see you in the window -- Wherever I go I hear your step behind me -- and I long to turn and hold my arms out and ask you to come back to me --

(KATE makes a sad, incredulous movement.)

Ah, wait - wait! Hear me out. This is no sudden conversion. I don't pretend that life together can ever be to us what it was before. There'll be moments when I believe you - - and others - - more, perhaps-- when I don't. I know well enough. There'll be happiness and misery-- as in most lives, I suppose, - - but all I ask is that - - just once more - - we should take our chance of them together- -

(She remains motionless, her head bowed, leaning against the table.)

Kate - Kate - don't tell me it's too late!

KATE

(Slowly)

It's too late.

DERWENT

(Falling back.)

Ah! - -

KATE

The moments when you believed in me would only make the others harder to bear.

DERWENT

Kate!

KATE

(Firmly.)

If I haven't convinced you yet nothing will ever convince you. 


\title{
LORD OSTERLEIGH
}

(Starting up.)

Nothing?

KATE

\author{
(Warningly.) \\ Lord Osterleigh!
}

\section{LORD OSTERLEIGH}

My word will convince him!

(HE takes Kate's hand and draws her toward him.)

I am here to answer for her, Derwent. Man - - take back your wife if you can get her!

\section{DERWENT}

(Overwhelmed.)

You - - Lord Osterleigh?

\section{LORD OSTERLEIGH}

I tell you I answer for her!

\section{DERWENT}

(Dazed.)

But this morning - - it was you - -

\section{LORD OSTERLEIGH}

Yes. But since then - -

\section{DERWENT}

You've found out?

$$
\text { DERWENT [SIC] }
$$

(Breaking out.)

$\mathrm{Ah}$ - - What is it that you're all keeping back from me? 


\section{LORD OSTERLEIGH}

Isn't my word enough?

(Speaking with a great effort.)

I solemnly exonerate your wife from all blame-- in -- in -- the matter of - Agnes's death - -

DERWENT

You - you - know then- -?

\section{LORD OSTERLEIGH}

Yes.

(A long pause.)

DERWENT

(Resolutely.)

And the proof--?

\section{LORD OSTERLEIGH}

You won't take my word for it?

\section{DERWENT}

\section{(Deeply agitated.)}

I -- ah -- my God -- no!

(He looks from one to the other.)

Why shouldn't I know the truth as well as you?

(There is another pause.)

\section{LORD OSTERLEIGH}

(Solemnly pointing to the paper in Kate's hand.)

The truth is there.

KATE

Ah! - - 


\section{DERWENT}

Kate! -

KATE

(Looking earnestly at Lord Osterleigh.)

Lord Osterleigh -- do I understand that you - - authorize me -- to -- to use this paper as I see fit?

\section{LORD OSTERLEIGH}

(With a final effort.)

As you - - see fit--

KATE

Then --

(She turns quickly, hold [sic] the paper over the lamp, and throws the flaming fragment into the grate, where it burns up in an instant.)

\section{LORD OSTERLEIGH}

(Irrepressibly.)

Oh, thank God-- thank God!

\section{KATE}

(To Lord Osterleigh, with a gesture toward the grate.)

Do you think the kind of happiness that could be bought with that would be worth having?

(To DERWENT, with a touch of pitying irony.)

Go now - walk past our house again - and - and see if I'm still in the window -(LORD OSTERLEIGH leans upon her feebly like an old man, and DERWENT, stunned and yet already penetrated by the sense of some great renewal, stands before her with bowed head as the curtain falls.)

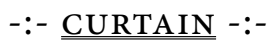




\section{Notes}

1. In the typescript, this page is preceded by a cover sheet, on which is centered and typed:

\section{-:- THE SHADOW OF A DOUBT -:-}

ACT I.

On the upper left corner of the page is a blue oval stamp and white lettering for three separate lines: "STENOGRAPHY/Nash/TYPEWRITING."

2. The second typescript prefaces the paragraph which opens "As the curtain rises" with the word

\section{"Discovered-:"}

3. The article "A" is missing from the second typescript.

4. The second typescript omits the emphasis on "are."

5. The second typescript omits the emphasis on "is."

6. The second typescript omits the emphasis on "is."

7. The second typescript omits "She" and begins, "Rises nervously".

8. The second typescript reads "Yes?"

9. The second typescript reads "No."

10. The article "a" is missing from the second typescript.

11. There is a page break at this point in the typescript, then a blank sheet. This is followed in the file by a cover sheet, on which is centered and typed:

\section{-:- THE SHADOW OF A DOUBT -:-}

\section{ACT II.}

The cover sheet for each act features on its upper left corner the blue oval typing stamp, described above. A different typing service stamp features on the second typescript: Rosenfield Stenography and Typewriting 49 West 28th St. 71 Broadway New York City.

12. The second typescript reads "Ha! ha! ha!"

13. The second typescript reads "interruption."

14. The second typescript uses the singular "right."

15. The second typescript uses the correct past tense "I meant to."

16. The word "Dear!" is omitted from the second typescript.

17. The second typescript reads "appears."

18. There is a page break at this point in the typescript, then a blank sheet. This is followed in the file by a cover sheet, again with the blue oval stamp and the (centered) typing:

\section{-:- THE SHADOW OF A DOUBT -:-}

\section{ACT III.}

19. Both typescripts cite "Sylvia," surely a misprint, which should read "Clodagh."

20. The second typescript uses the singular "being."

21. Both typescripts cite "love," rather than "live." 